\title{
37. THE GOBAN SPUR OF THE NORTHEAST-ATLANTIC MARGIN DURING LATE CRETACEOUS TIMES ${ }^{1}$
}

\author{
Pierre Charles de Graciansky, École Nationale Supérieure des Mines de Paris \\ and \\ Maurice Bourbon, École Nationale Supérieure des Mines, Sophia-Antipolis ${ }^{2}$
}

\begin{abstract}
The Late Cretaceous depositional history of the continental margin across the Goban Spur can be divided into two episodes, sediment records of which are separated by an upper Campanian unconformity traceable from the foot to the top of the margin.

Below the unconformity, there was no deposition at the shallowest site (548), and deposition of relatively short sequences of foraminiferal and nannofossil-bearing white chalks, with indications of hiatuses or condensation, took place at the two sites of intermediate depth (549 and 551). The varied clay-mineral associations show a marked terrigenous influx superimposed on the mostly biogenic calcareous sedimentation.

A 1-m-thick bed of carbonaceous shale and radiolarian chert interbedded with low-TOC white chalks was drilled at the boundary between the Cenomanian and the Turonian of Sites 549 and 551. Interpretations of this lithology are discussed.

Above the unconformity, layers of nearly pure chalks (upper Campanian to Maestrichtian), with frequent signs of redeposition, blanket the whole margin, except for the steeper slopes like the Pendragon Escarpment.

The Albian ocean crust drilled at Site 550 lay farther from the contemporary shore line than the other drill sites. In the Cenomanian the still narrow oceanic trough received nearly pure calcareous mudstones under alternating conditions of poorly and normally oxygenated bottom water. A sediment gap at Site 550 spans the upper Cenomanian and the whole of the Turonian. From the lower Senonian to the lower Paleocene, chalky turbidites are interbedded within hemipelagic mudstones. Deposition probably took place beneath the CCD in the early Senonian. The mineralogical composition of the hemipelagic part of these turbidites shows a significantly greater terrigenous influence than coeval deposits at shallower sites.
\end{abstract}

\section{INTRODUCTION}

Four boreholes across the continental margin at the Goban Spur (Sites 548-551; Figs. 1 and 2) allowed us to follow the evolution of the paleoenvironments at different paleodepths in the same area. Upper Cretaceous chalks and associated sediments deposited during the early stages of seafloor spreading document a turning point in the subsidence history of the whole margin, also reflected by an upper Campanian disconformity of regional extent. Below the disconformity, seismic reflection profiles show the existence of half-grabens inherited from the rifting period, which had a relatively independent sedimentary evolution (site chapters, this volume). During and after the late Campanian (after the infilling of the half-grabens), uniform chalk sedimentation took place, reflecting a bloom in productivity of calcareous nannofossils and planktonic foraminifers.

The deposits considered here can therefore be divided into two parts:

1. Cenomanian to Santonian sediments of variable lithology, namely white chalks (Site 549) and dark shales interbedded within redeposited chalks (Site 550). No deposition of this age is recorded at Site 548 .

\footnotetext{
${ }^{1}$ Graciansky, P. C. de, Poag, C. W., et al., Init. Repts. DSDP, 80: Washington (U.S. Govt, Printing Office).

2 Addresses: (Graciansky) École National Supérieure des Mines de Paris, 60, Boulevard Saint Michel, 75272 Paris, Cedex 06, France; (Bourbon) École Nationale Supérieure des Mines, Sophia-Antipolis, 06565 Valbonne, Cedex 06, France.
}

2. Upper Campanian to lower Paleocene chalks of relatively uniform lithology, bound at the bottom by the upper Campanian disconformity and at the top by another disconformity of widespread extent corresponding to a sharp lower upper Paleocene lithologic change.

The objective of this paper is to describe the main lithologic units and to reconstruct the depositional conditions during this critical period, which lasted through part of the Late Cretaceous.

Lithological, mineralogical, and sedimentological features of the deposits are discussed site by site. Methods of investigation included visual inspection of the cores, standard microscopic thin-section examination, and scanning-electron microscope study of surfaces of broken samples and of replicas obtained by impregnation with a plastic resin. Additional data were provided by standard $\mathrm{X}$-ray mineralogical determinations. Dating is derived from foraminifer and nannofossil studies (site chapters, this volume, and Müller, this volume).

\section{SITE 548 (HOLE 548A)}

At this shallowest site of the transect $(1256 \mathrm{~m}$ water depth), $61 \mathrm{~m}$ of upper Campanian to Danian white chalks were drilled in Hole 548A (Core 35 to Core 28, Section 6: $531-470 \mathrm{~m}$ sub-bottom).

The lower boundary of the chalks was not recovered. The core-catcher sample of Core 35 contains fragments of hard glauconitic chalky limestone and a piece of sideritic and phosphatic hardground (Karpoff et al., this 


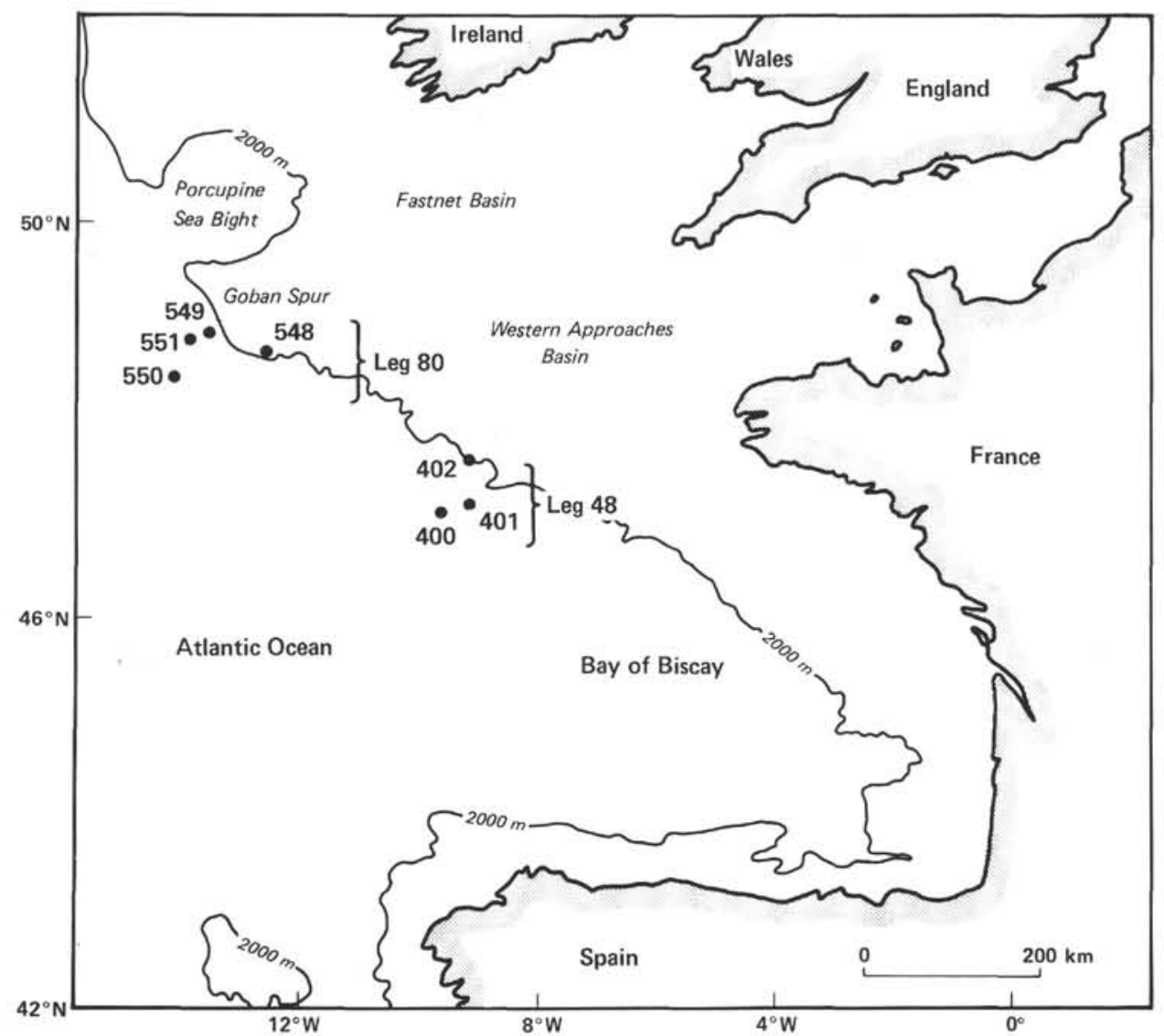

Figure 1. Site location map.

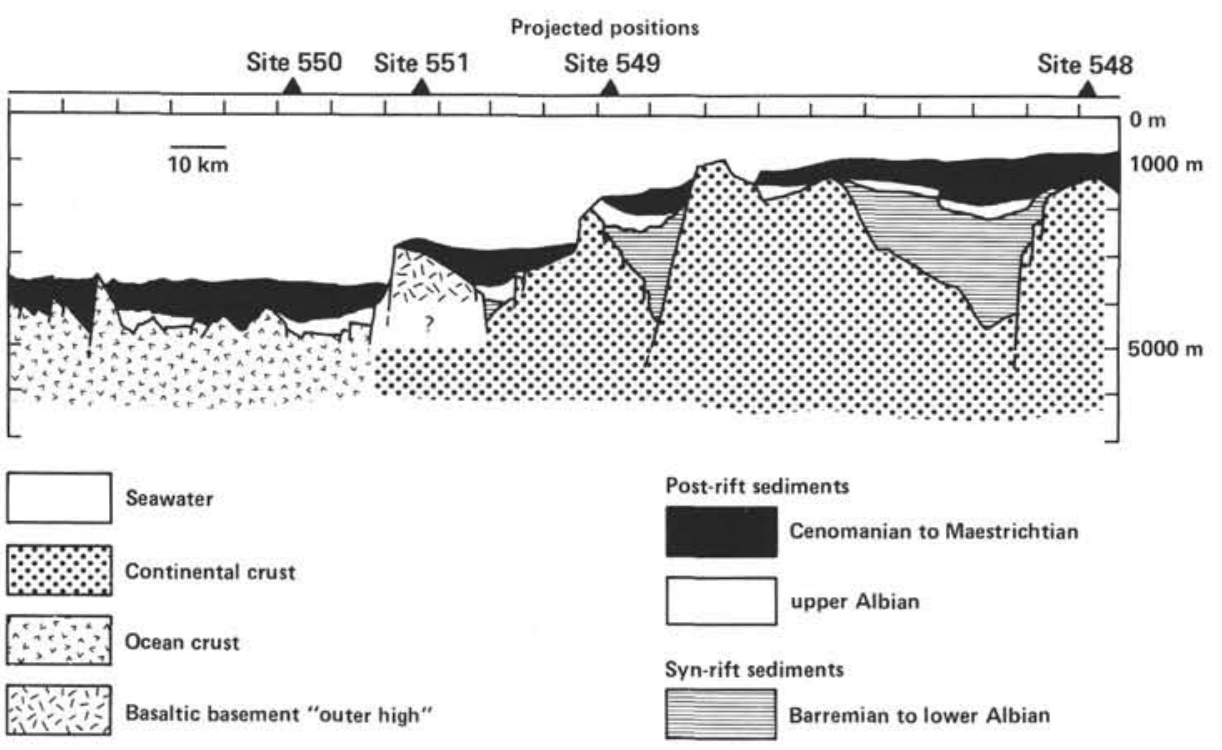

Figure 2. Profile across the Goban Spur margin for 65 m.y. ago (end of the Cretaceous). This profile was reconstructed by "backstripping" (Masson et al., this volume).

volume). These are separated from Devonian quartzites by an unrecovered interval of almost ten meters.

The upper boundary is a sharp, disconformable contact with lower Eocene brown marly nannofossil chalks (Section 28-6, $71 \mathrm{~cm}$ ). Up to $40 \mathrm{~cm}$ above this contact, blocks of strongly burrowed Danian white chalk occur within the Eocene brown chalk (site chapter, this volume).

Nannofossils and planktonic foraminifers (site report, this volume) show the presence of the upper Campanian (MCS8 Zone), the whole Maestrichtian (Zones MCS9, 10, and 11), and the Danian (foraminiferal Zone P1a- 
P1c and nannofossil Zone NP2). Most of the section, however, is dated as Maestrichtian (Cores 34-29).

Thin sections (Fig. 3) show the sparsity of bedding surfaces and the prevalence of burrowing. The abundance of planktonic foraminifers decreases from bottom to top (10-20\% in the upper Campanian to less than $10 \%$ in the uppermost Maestrichtian), with one exception at $29-1,36-42 \mathrm{~cm}$. Inoceramus prisms are widespread throughout; their abundance is less than $5 \%$, with a maximum in the middle Maestrichtian. The preservation of Inoceramus prisms is good (Plate 6, Fig. 2) to poor (Plate 6, Fig. 4), as shown by scanning-electron micrographs. Recrystallization and poor preservation of foraminifers (site chapter, this volume) and of calcareous nannofossils (Müller, this volume) have also been observed. A few echinoid spines and unspecified millimeter-sized shells have probably been reworked from shallower depth.

Quartz is very rare or absent in thin sections. X-ray diagrams (Fig. 3) show only traces of quartz and sheet silicates. The sediments consist almost exclusively of biogenic and diagenetic calcite, as shown by the high content of $\mathrm{CaCO}_{3}$ (95 and $100 \%$; Cunningham et al., this volume). Terrigenous influx is documented only by a diversified clay-mineral association with smectite, mixedlayer clay minerals, illite, kaolinite, and minor chlorite.

The rich foraminiferal assemblage is considered characteristic of a pelagic outer shelf environment, which means 100 to $300 \mathrm{~m}$ average depth (site chapter, this volume). This figure is roughly in accordance with water depth derived from geophysical considerations, which take into account thermal decay, weight of sediments, and eustatic variations of sea level (Fig. 2 and Masson et al., this volume). Sedimentary structures like mud balls and contorted bedding suggest down-slope transport from shallower sites by slumping and sliding.

\section{SITE 549 (HOLE 549)}

At this site near the edge of the Pendragon Escarpment (2515 m water depth), lower middle Cenomanian to Maestrichtian nannofossil chalks were recovered in Hole 549 (Cores 31-21, 479-379 m sub-bottom).

The lower boundary of the chalks was not recovered (zero recovery in Cores 30 and 31 ), but it can be accurately placed at $479 \mathrm{~m}$ sub-bottom on the basis of a sharp change in lithology recorded on the logging curves. The underlying unit comprises middle Albian gray calcareous siltstones. Therefore, the interval between Core 29 (445.5 $\mathrm{m}$ sub-bottom), dated as middle Cenomanian (MCS1 Zone) and Core $32(483.5 \mathrm{~m})$, dated as middle Albian, spans a very condensed sequence or more probably a gap in sedimentation of some 10(?) m.y.

The upper boundary which occurs between Cores 20 and 21 was also not recovered. However, biostratigraphic data suggest that a disconformity encompassing a period of 6 to $7 \mathrm{~m}$.y. separates the Maestrichtian white chalks from upper Paleocene gray siliceous nannofossil chalks.

Nannofossil (Müller, this volume) and foraminiferal biostratigraphy show the existence of a hiatus dated as uppermost Cenomanian or lowermost Turonian, and an-

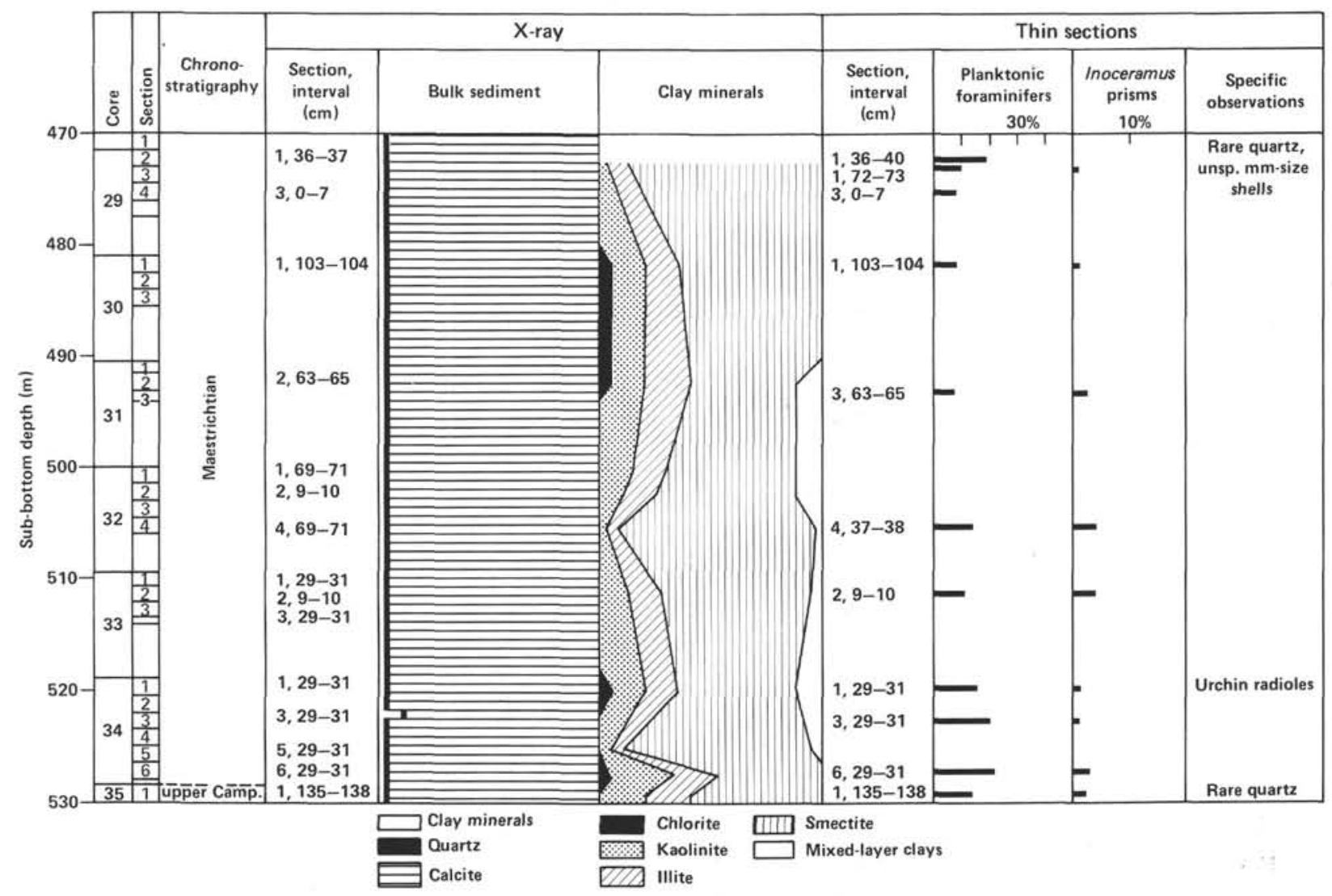

Figure 3. Main components of some typical Upper Cretaceous chalks, Hole 548A. 
other disconformity occurs between the Santonian and the Campanian. The very low sediment accumulation ( $100 \mathrm{~m}$ of deposits for some $35 \mathrm{~m} . \mathrm{y}$.) can be explained partly by these disconformities and hypothetical gaps of short duration which cannot be detected by biostratigraphic determinations. This slow deposition may be related to the location of the site on the top of an escarpment inherited from the rifting period. The seismic profile $\mathrm{CM}$ 10 shows how the chalky unit drilled at Site 549 thickens toward the half-graben located farther to the northeast.

The homogeneous sequence of these highly calcareous chalks $\left(\mathrm{CaCO}_{3}\right.$ contents reaching $\left.90-95 \%\right)$, deposited in a well-oxygenated environment (TOC $0.1 \%$ ), is interrupted by a 1 -m-thick layer of carbonaceous black shale associated with radiolarian cherts at $436 \mathrm{~m}$ subbottom (Core 27). The presence of opal-CT in the underlying Cenomanian chalk (Fig. 4) indicates the former presence of radiolarians in this chalk, which in turn points to a high organic productivity during Cenomanian time.
Reddish brown chert nodules are present in Cores 26, 25 , and 24 (site chapter, this volume). Burrowing is pervasive.

Sliding and slumping document the importance of redeposition of previously deposited sediments; mud balls are especially conspicuous in Core 23 (Plate 1).

Thin sections (Fig. 4) show a decreasing content of planktonic foraminifers from the Cenomanian (up to $40 \%$ in Core 28) to the Maestrichtian (less than $5 \%$ in Core 21). Inoceramus prisms also decrease from $20 \%$ in Core 28 to less than $5 \%$ in Core 21 (Fig. 4). Scattered quartz grains are visible in nearly all the studied sections, except in the Maestrichtian, where they are very rare or absent. The Cenomanian chalks (Cores 29 and 28) are the coarsest sediments of the Upper Cretaceous sequence, with 50 to $55 \%$ of the examined thin sections occupied by foraminifers, Inoceramus prisms, and quartz grains. Nannofossils are not very abundant, probably owing to poor preservation. In contrast, the Maestrichtian sedi-

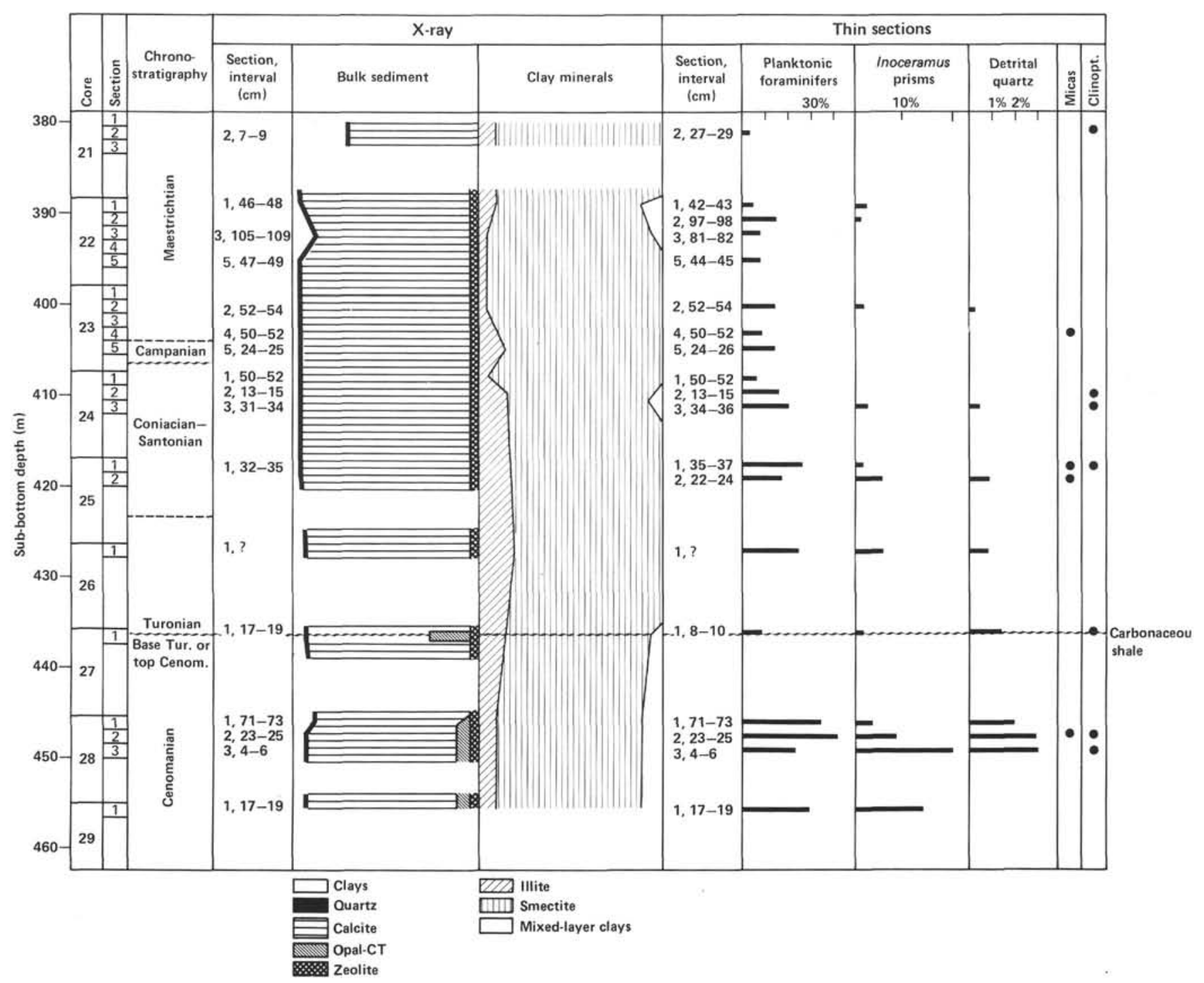

Figure 4. Main components of some typical Upper Cretaceous sediments, Hole 549. 
ments are nearly pure chalks, with abundant and wellpreserved nannofossils (Müller, this volume) and relatively rare foraminifers. The sediments in between show intermediate faunal and floral abundances and intermediate stages of preservation of calcareous micro- and nannofossils. The mineralogical assemblages are roughly comparable to those of Site 548 (Fig. 4). The total amount of calcium carbonate is somewhat lower, with clay-mineral contents reaching 5 to $10 \%$ in the Cenomanian and 20 to $25 \%$ in the Maestrichtian (Fig. 4), compared with less than $5 \%$ at Site 548 , as demonstrated by shipboard "carbonate bomb" measurements. However, the quartz content is still very low. The clay-mineral assemblage is less varied than at Site 548 , with smectite dominant, associated with illite and subordinate mixedlayer clay minerals. This probably reflects the remoteness from any terrigenous detrital source. The abundance of opal-CT in the Cenomanian and of scattered clinoptilolite all through the section indicates the former presence of radiolarians. Their scarcity in sieve residues may be a result of diagnetic dissolution.

The reduced thickness of the Upper Cretaceous section at Site 549 (approximately one or two cores for one stage) and the numerous redeposited intervals may be related to the location of Site 549 near the top of an escarpment. Its location at an intermediate depth on the Goban Spur continental slope is not compatible with the occurrence of outer sublittoral to upper bathyal foraminiferal assemblages (site chapter, this volume). These must have been redeposited between approximately 1000 and $1500 \mathrm{~m}$ water depth. This latter figure is derived from backtracking of the site (Masson et al., this volume).

\section{SITE 551 (HOLE 551)}

\section{Introduction}

This site is at the seaward edge of the basement "outer high," in $3909 \mathrm{~m}$ of water. Upper Cenomanian to lower Maestrichtian chalks were found directly overlying pillow basalts (Cores 6 to 2 and H2, 142.4-100.9 m sub-bottom; site chapter, this volume).

The contact with the oceanic basalts is sharp; pinkish micritic infillings are present between the altered pillows.

The upper boundary, a sharp contact between upper Paleocene yellow-brown chalks and lower Maestrichtian light gray chalks, was recovered within Core H2, Section 5 .

The Upper Cretaceous section, only $41.5 \mathrm{~m}$ thick, is divided into three parts by two discontinuities. The upper one lies at $130 \mathrm{~m}$ sub-bottom (between Cores 5 and 4); its hiatus includes foraminiferal Zones MCS4, 5, 6, and 7 (site chapter, this volume). It separates the lower Turonian from the upper Campanian, and can be correlated with a disconformity of regional extent. The lower discontinuity corresponds to a $1-\mathrm{m}$-thick layer of carbonaceous shales interbedded with the white chalks. Upper Cenomanian strata (foraminiferal Zone MCS2) are present below this dark shale layer, and lower Turonian (Zone MCS3) beds rest above. Such a peculiar layer is comparable to that, already mentioned, at Site 549 , and implies sufficient organic productivity and/or temporary stagnation of bottom waters to allow preservation of marine organic matter (see Waples, "Anoxia," this volume).

\section{Main Subdivisions}

On the basis of these two disconformities, the Upper Cretaceous chalks can be divided into three units; the black shale layer is excluded from the present description (Fig. 5).

\section{Upper Cenomanian Chalks}

At Site 551, the sediments at depths from 142.4 to $138.5 \mathrm{~m}$ sub-bottom (Section 6-3, $92 \mathrm{~cm}$ through Section 1) are part of the foraminiferal MCS2 Zone. These sediments are massive, with occasional zones of bedding or lamination. Dominant colors are white and pale yellow. Laminae consist of accumulations of planktonic foraminifers (up to $30 \%$ of the surface) and/or of Inoceramus prisms (up to 20\%) (Plate 5, Fig. 9, Plate 6, Fig. 3 ) and small quartz grains (1\%), as seen in thin sections. Stereoscan micrographs and light-optical examination (Müller, this volume) show moderately well preserved nannofossils with calcite overgrowth, as well as recrystallization of foraminifers (site report, this volume). From X-ray diffraction data (Fig. 5) it may be assumed that the Cenomanian chalks are nearly pure calcium carbonate (90-95\%) associated with clay minerals $(10 \%$ at most) and traces of quartz. Clinoptilolite forms up to $5 \%$ of the bulk rock, and is visible in thin sections. The clay-mineral assemblage comprises smectite $(80-20 \%)$, illite $(10-30 \%)$, and mixed-layer clay minerals $(10-80 \%)$ in similar proportions, which shows a stronger terrigenous influence than in the upper parts of the chalks, where smectites are widely dominant.

\section{Lower Turonian Chalks}

The sediments at depths from 134.6 to $132.5 \mathrm{~m}$ subbottom (Section 5-2, $60 \mathrm{~cm}$ through Section 1) belong to the foraminiferal MCS3 Zone. Two meters of massive or faintly laminated chalk were recovered. Colors range from white to pale green. Shipboard carbonate determinations of the bulk sediment show $\mathrm{CaCO}_{3}$ contents in the more calcareous lithologies varying from 40 to $75 \%$. Two gritty, 2- to 3-cm-thick horizons occur in Section 2; they are rich in radiolarians, opal, and zeolites, and contain less than $10 \% \mathrm{CaCO}_{3}$.

$\mathrm{X}$-ray mineralogical analysis of the bulk sediment (Fig. 6) shows quartz only in traces and a total clay-mineral content of less than $10 \%$, with smectite dominant over illite. The remainder is clinoptilolite and barite, indicating important diagenetic reactions in this section. Nevertheless, the planktonic foraminifers and the calcareous nannofossils are relatively well preserved.

The development of diagenetic minerals is probably enhanced by (1) the relatively coarse grain-size of the radiolarian-rich layers, which is favorable to fluid circulation, and (2) the redox disequilibrium between well-oxygenated chalks and the reduced carbonaceous layer of Section 5-2. 


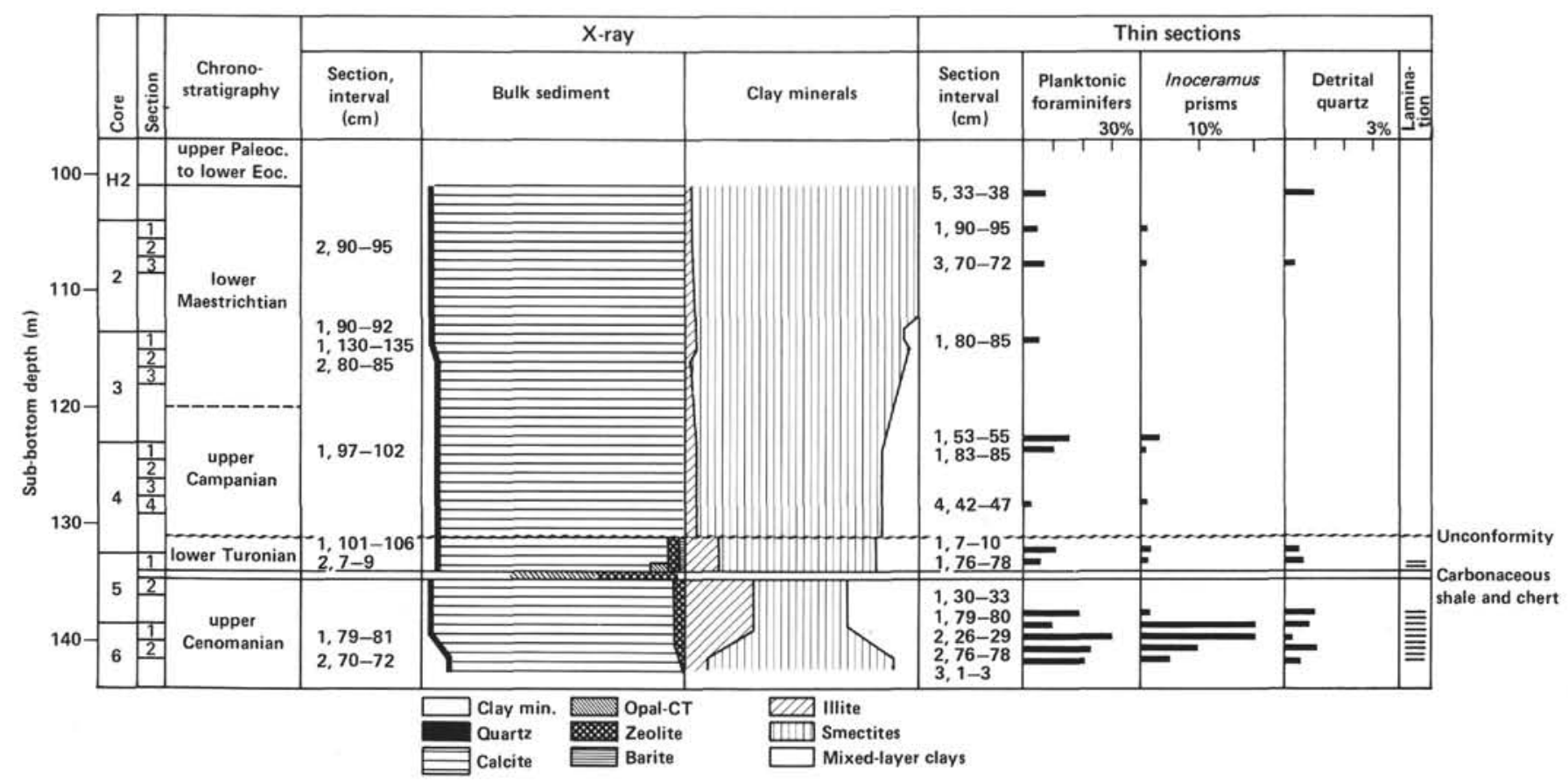

Figure 5. Main components of some typical Upper Cretaceous sediments, Hole 551.

\section{Upper Campanian to Lower Maestrichtian Oozes and Chalks}

These sediments, at depths from 132.5 to $100.9 \mathrm{~m}$ subbottom (Core 4 through Core H2, Section $5,40 \mathrm{~cm}$ ), were designated upper Campanian to lower Maestrichtian on the basis of micro- and nannofossils. The dominant color is light gray. Sedimentary structures indicating gravitational redeposition are typical for this approximately 30 $\mathrm{m}$-thick section. Mud balls of white chalks, which contain shallow-water foraminifers, are included in unbedded, bioturbated, contorted grayish chalks containing microfaunas characteristic of deeper environments (site chapter, this volume). Thin sections (Fig. 5) show sparse planktonic foraminifers and very rare Inoceramus prisms, but no quartz. Preservation of calcareous nannofossils and of foraminifers is moderate to good (Müller and site chapter, this volume), and calcite overgrowth on calcareous nannofossils is not present to a significant degree, as shown by scanning-electron microscopy.

These Campanian-Maestrichtian deposits are almost pure chalks with at least $90 \% \mathrm{CaCO}_{3}$ (carbonate-bomb analysis), together with minor amounts of clay minerals and traces of quartz. Clay minerals comprise approximately $80 \%$ smectite with subordinate illite and mixedlayer clay minerals in the Campanian, grading upward into an assemblage of nearly pure smectite in the Maestrichtian.

\section{Conclusion}

According to paleodepth reconstructions (Masson et al., this volume), the distal part of the margin around Site 551 underwent rapid subsidence of some $1500 \mathrm{~m}$ during the Late Cretaceous. Water depth at the Cretaceous/Tertiary boundary was approximately $2500 \mathrm{~m}$. The main lithologic characteristics of the Upper Cretaceous chalks at Site 551 are (1) the strongly reduced thickness of the sequence (less than $50 \mathrm{~m}$ for $35 \mathrm{~m} . \mathrm{y}$.), (2) the frequency of stratigraphic gaps, and (3) the frequency of redeposited intervals. All this reflects (1) the proximity of the site to the edge of an escarpment, near the foot the continental slope, (2) the remoteness from any source of detrital material at a time when the basement was already buried by a relatively thick cover of sediments, and (3) a high biogenic productivity of calcareous organisms during a time of high sea level.

\section{SITE 550 (HOLES 550 AND 550B)}

\section{Location and Main Lithologies}

This site was drilled on the Porcupine Abyssal Plain in $4420 \mathrm{~m}$ water depth, the greatest of our transect. In the Upper Cretaceous, three main units can be separated according to age and lithology:

1. Alternating carbonaceous and non-carbonaceous calcareous siltstones, uppermost Albian to middle Cenomanian (thickness $125.67 \mathrm{~m}$; Unit 5; site chapter, this volume).

2. Dark claystones interbedded with turbiditic calcareous mudstones, Santonian to Coniacian (thickness $20 \mathrm{~m}$; Unit 4; site chapter, this volume).

3. Marly nannofossil chalks interbedded with calcareous turbidites and mudflows (upper Campanian to lower Paleocene; thickness $148.5 \mathrm{~m}$; Unit 3; site chapter, this volume).

\section{Description of the Main Units}

\section{Unit 5: Alternating Carbonaceous and Non-Carbonaceous Calcareous Siltstones}

This unit was drilled from 594.83 to $685.37 \mathrm{~m}$ subbottom in Hole 550B (15-4, $83 \mathrm{~cm}$ to $25-4,87 \mathrm{~cm})$. Pale- 


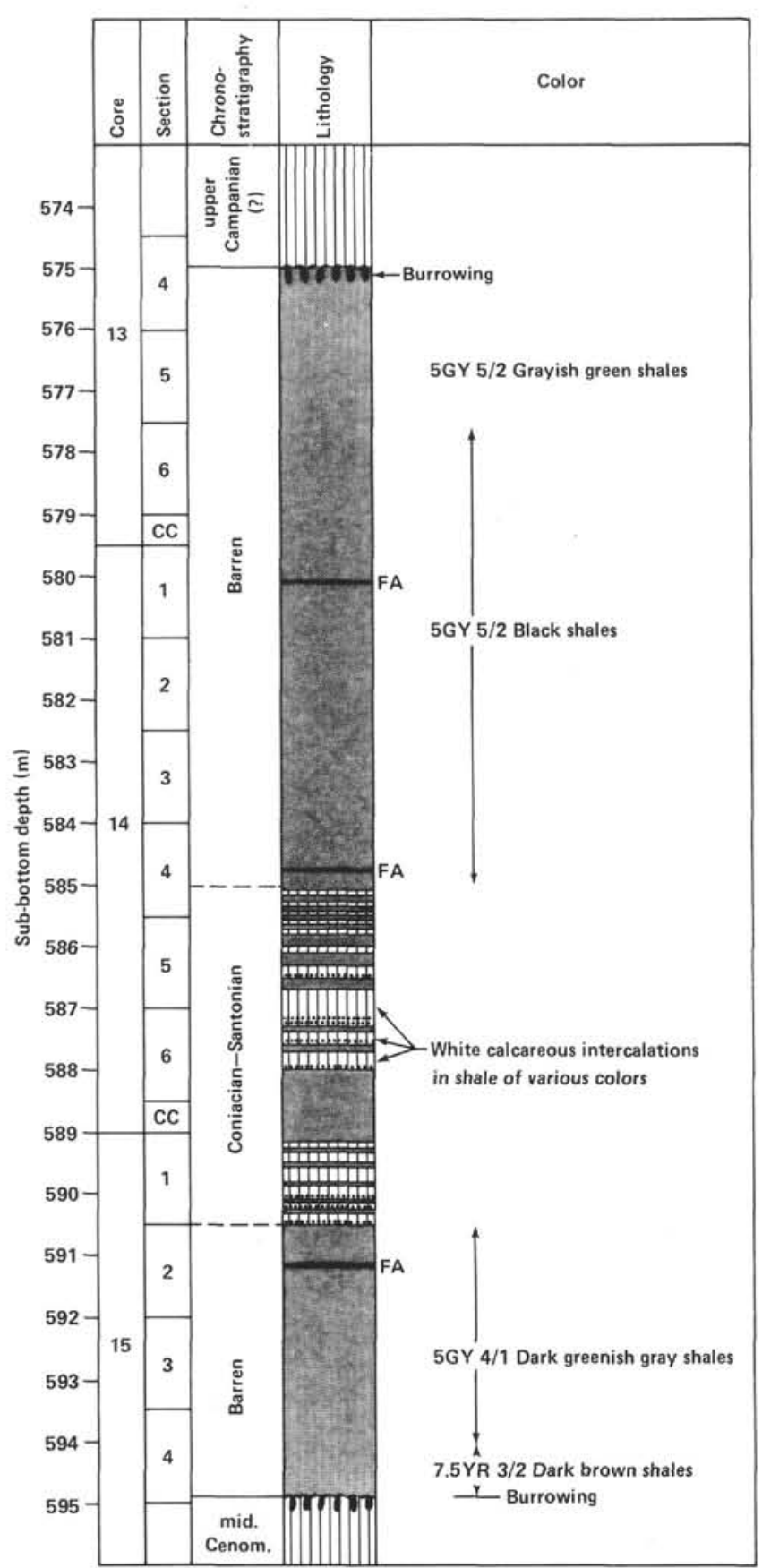

Figure 6. Diagrammatic succession of the lower Senonian sediments, Hole 550B (Cores 13-15). White calcareous mudstones are interbedded within dark shales. FA $=$ Fluorapatite. Dots at base of intercalations represent grading.

ontological evidence indicates middle Cenomanian to uppermost Albian chronostratigraphy. Unit 5 is composed of calcareous siltstones whose mineralogical composition is similar to that of the coeval deposits at Site 549: calcite is 60 to $80 \%$ of the bulk sediment, with minor clay minerals and quartz; the clay-mineral association comprises dominantly smectite but also small amounts or traces of illite, mixed-layer clay minerals, chlorite, and kaolinite, reflecting terrigenous influx. A characteristic of these layers is the alternation of white and dark colors, caused by variations in the content of organic matter, which is partly derived from marine organisms (Waples, this volume). Such variations may be related to cyclic fluctuations of stagnation and aeration of the bottom waters (see Graciansky and Gillot, this volume).

\section{Unit 4: Dark Claystones and Turbiditic Calcareous Mudstones}

These lithologies lie between 594.83 and $575 \mathrm{~m}$ subbottom in Hole 550B (15-4, $83 \mathrm{~cm}$ to $13-3,67 \mathrm{~cm})$. Their chronostratigraphic position is Santonian to Coniacian. The lower boundary is a strongly burrowed contact between Cenomanian calcareous siltstones below and Coniacian dark claystones above (Fig. 6). The upper boundary is also a strongly burrowed surface, covered by upper Campanian chalks (Plate 3, Fig. 3). A lower Senonian assignment is indicated by foraminifers and nannofossils (site chapter, this volume; Müller, this volume), which are particularly abundant in the lower half of the section, which contains the calcareous interbeds. The upper half, which is mainly argillaceous, contains only agglutinating foraminifers with little stratigraphic value. Because nannofossils are absent from the uppermost $9 \mathrm{~m}$, the age of this short interval is uncertain.

The main part of the unit is composed of dark claystones with less than $5 \% \mathrm{CaCO}_{3}$. According to $\mathrm{X}$-ray analysis, clay minerals are widely dominant over quartz (15-20\% of the bulk sediments), and only traces of plagioclases occur (Table 1). Among the clay minerals, smectites make up 95 to $100 \%$, together with minor illite and mixed-layer clay minerals. Grains determinable in the sieve residues are fish debris, agglutinating foraminifers, and radiolarians, together with rare quartz, pyrite, and micas. The sediments are mainly dark gray, dark greenish gray, or black. At the base of the unit (Section 15-4), however, the (dark) brownish colors suggest that the depositional and/or diagenetic environments were favorable to the development of oxidized iron instead of pyrite, a widespread mineral in the overlying beds.

Calcareous layers (Fig. 7) ranging from 10 to $60 \mathrm{~cm}$ in thickness are interbedded within the dark shales from Section 14-4 through Section 15-1. The lower contacts of these layers are sharp and probably erosional, but the upper ones are gradational and highly bioturbated (Fig. 7). The calcareous interbeds may therefore be interpreted as muddy calcareous turbidites, but in thin section they appear to be only poorly graded. Inoceramus prisms, planktonic foraminifers, quartz, glauconite, and mica grains are present in similar proportions from top to bottom of each individual bed. The remainder is mostly calcareous nannofossils. The $\mathrm{CaCO}_{3}$ content reaches $80 \%$. Results of thin-section examination of samples from the lower Senonian section of redeposited calcareous mudstones (Hole 550B) are presented in the following tabulation. 
Table 1. Mineralogical biogenic components of lower Senonian sediments at Site 550.

\begin{tabular}{|c|c|c|c|c|c|c|c|c|c|c|c|c|c|c|}
\hline & \multicolumn{7}{|c|}{$\begin{array}{l}\text { Mineralogical composition in percent } \\
\text { (X-ray determination) }\end{array}$} & \multicolumn{7}{|c|}{ Sieve residue } \\
\hline & Calcite & Quartz & $\begin{array}{l}\text { Plagio- } \\
\text { clase }\end{array}$ & $\begin{array}{l}\text { Clay } \\
\text { minerals }\end{array}$ & Illite & $\begin{array}{c}\text { Smec- } \\
\text { tite }\end{array}$ & $\begin{array}{l}\text { Mixed- } \\
\text { layer }\end{array}$ & Quartz & Micas & $\begin{array}{l}\text { Glau- } \\
\text { conite }\end{array}$ & Pyrite & $\begin{array}{l}\text { Inoce- } \\
\text { amus } \\
\text { prisms }\end{array}$ & $\begin{array}{l}\text { Radio- } \\
\text { larians }\end{array}$ & Foraminifers \\
\hline $\begin{array}{l}\text { Black } \\
\quad \text { claystones }\end{array}$ & $\mathrm{T}$ & $\begin{array}{l}15 \\
20\end{array}$ & $\mathrm{~T}$ & $\begin{array}{l}75 \\
80\end{array}$ & $\begin{array}{l}0.5 \\
0\end{array}$ & $\begin{array}{l}9.5 \\
10\end{array}$ & $\mathrm{~T}$ & \pm & $\mathrm{T}$ & $\mathrm{R}-\mathrm{C}$ & + & 0 & \pm & Agglutinating \\
\hline $\begin{array}{l}\text { Redeposited } \\
\text { calcareous } \\
\text { mudstones }\end{array}$ & 80 & $\mathrm{~T}$ & 0 & 20 & & & & \pm & 0 & & $0-\mathrm{T}$ & A & \pm & $\begin{array}{l}\text { Planktonic and } \\
\text { benthic }\end{array}$ \\
\hline
\end{tabular}

Note: $\mathbf{A}=$ abundant, $\mathrm{C}=$ common, $\mathrm{R}=$ rare, $\mathrm{T}=$ trace, $0=$ absent.

\begin{tabular}{|c|c|}
\hline Quartz: & Trace \\
\hline Micas: & Rare to absent \\
\hline Glauconite: & Trace \\
\hline Pyrite: & Absent? \\
\hline Inoceramus prisms: & Trace \\
\hline Radiolarians: & Absent? \\
\hline Foraminifers: & $\begin{array}{l}\text { Planktonics widely dominant; trace } \\
\text { of calcareous benthic and ag- } \\
\text { glutinating forms }\end{array}$ \\
\hline Sorting: & Very poor \\
\hline
\end{tabular}

We interpret the dark claystones as indicating hemipelagic sedimentation in the deep ocean, to which only clay minerals and fine quartz from distant continental sources were transported. Dissolution of the carbonate is partial in the lower part of the subunit but complete in the upper part. Preservation of the calcareous material in the limestone layers may be explained by the rapid gravitational transport and burial of the sediment on the seafloor-which was below the CCD during the early Senonian (approximately $3000 \mathrm{~m}$, from backtracking estimates; Masson et al., this volume)-or by (climatic?) oscillations of the CCD at this time.

After deposition, fluorite and phosphorus, probably of biogenic origin, were concentrated within tiny veins of fluorapatite. This suggests the importance of late diagenetic processes, together with the evolution of the clay-mineral assemblage into a nearly pure smectite association.

\section{Unit 3: Marly Nannofossil Chalks Interbedded with Calcareous Turbidites and Mud Flows}

Unit 3 extends between $575 \mathrm{~m}$ (Hole 550B, 13-3, 50 $\mathrm{cm}$; Hole 550, Core 47) and $426 \mathrm{~m}$ sub-bottom floor (Hole 550B, Core 1; Hole 550, 36-3, $95 \mathrm{~cm}$ ). Its chronostratigraphic position is upper Campanian to lower upper Paleocene. The lower boundary of this unit corresponds to a burrowed surface already mentioned in the discussion of Unit 4 . The upper boundary is defined by a concentration of manganese and phosphate deposited along an unconformity within the lower upper Paleocene (Karpoff et al., this volume).

The Cretaceous/Tertiary boundary could not be studied in detail because of poor recovery. The boundary is located near the depth at which Hole 550 was abandoned and Hole 550B was first cored. This situation hampered the correlation between the two holes.

Inspection of the sparsely recovered sections reveals a progressive evolution of lithologies from the Maestrichtian to the Paleocene deposits, but no clear break in sedimentation. This justifies description of Paleocene chalks within this chapter, which in principle is devoted to Upper Cretaceous deposits.

The main characteristics of the Paleocene are the presence of opal-CT, clinoptilolite, and a nearly pure smectite clay-mineral association, which are not observed in the Upper Cretaceous.

Four subunits can be defined by fluctuations in the minimum $\mathrm{CaCO}_{3}$ content, as expressed on the curves in Figure 8.

According to the abundant foraminifers and nannofossils, sedimentation was continuous during deposition of this unit. However, some fluctuations have been as shown by downhole measurements and mineralogical determinations (Figs. 8-10), which allowed the following definition of subunits.

\section{Unit 3, Part 1}

This subunit lies between $575 \mathrm{~m}$ sub-bottom in Hole $550 \mathrm{~B}(13-3,50 \mathrm{~cm})$ and approximately $510 \mathrm{~m}$ (within Core 6 , which was not recovered). The subunit is early Maestrichtian in age. In this subunit more and less calcareous lithologies alternate.

The more calcareous layers represent the lower intervals of individual turbiditic cycles, where $\mathrm{CaCO}_{3}$ contents range between 75 and $95 \%$ (Fig. 9 and Plate 3, Fig. 2). The lowermost parts of these cycles overlie erosive surfaces, and are relatively coarse grained and well sorted. The coarser particles include very abundant calcareous foraminifers, abundant Inoceramus prisms, and a few quartz grains (Plate 6, Figs. 1 and 6). The upper parts of the calcareous layers consist almost entirely of calcareous nannofossils.

The less calcareous marly chalks $\left(\mathrm{CaCO}_{3}\right.$ contents 35$65 \%$, from onboard measurements) constitute the upper parts of the turbidite beds. Coccoliths and clay minerals are the main components, accompanied by rare fish debris, sponge spicules, Inoceramus prisms, and small globigerinids. These upper "hemipelagic" parts of the turbidites are highly bioturbated. A pinkish to reddish col- 


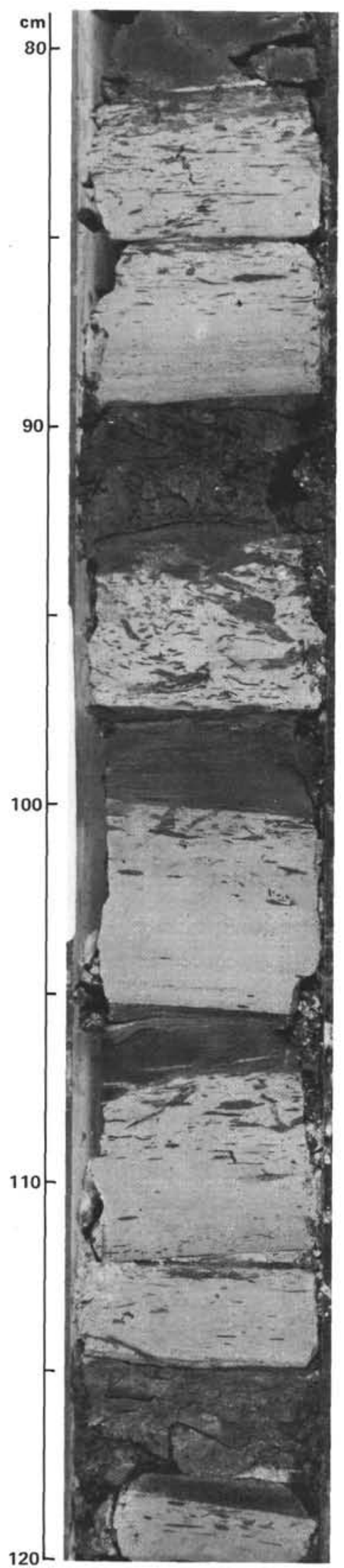

Figure 7. Calcareous interbedding with dark smectitic shales in the lower Senonian, Hole 550B (14-4, 78-120 cm). or, which contrasts with the white color of the other lithologic type, arises from small amounts of hematite (Plate 3, Fig. 2).

The clay-mineral assemblage (Fig. 10) shows a similar evolution in both lithologies. In the "hemipelagic" marly nannofossil chalks, smectite dominates $(80-95 \%)$ over illite and minor kaolinite in Cores 13 and 12; upsection, the proportions of kaolinite and illite increase, and chlorite and mixed-layer clay minerals appear in Cores 11 to 7. In some samples from Cores 7 through 9, smectite content is only $20 \%$. In the redeposited chalks of Core 12 , smectite is nearly the only clay mineral; but upward, in Cores 11 through 7, chlorite, kaolinite, illite, and mixed-layer clay minerals appear in small proportions with 50 to $70 \%$ of smectite.

The above observations show (1) a difference in origin between the two lithologies; (2) the terrigenous origin of a large part of the marly nannofossil chalks, the varied assemblage of clay minerals indicating a deeply eroded continental source area; and (3) the increase of terrigenous influx through the early Maestrichtian.

As mentioned before, this subunit comprises a repetition of the turbiditic cycles, documenting a redeposition of fine-grained chalks from shallower sites. In addition, Core 8 contains a coarse-debris flow deposit which grades upward into a sandy, weakly laminated layer (base at Section $5,90 \mathrm{~cm}$ ). In thin section, the coarser elements appear to be mud pebbles, grains of quartz, glauconite, mica schists, quartzites, calcareous sandstones, and fragments of Inoceramus shells. Nannofossils date a few of these lithic elements as Albian (onboard observation by C. Müller; July 1981). Lithologies and ages of these sediments show that mass-flow processes were involved in the transport of older sediments and even fragments of basement rocks.

\section{Unit 3, Part 2}

The sediments in Hole 550B at sub-bottom depths from $510 \mathrm{~m}$ (Core 6) to $470.35 \mathrm{~m}(2-3,36 \mathrm{~cm})$ were dated as late Maestrichtian. In this subunit, turbidite cycles are comparable to those of the underlying one. However, the $\mathrm{CaCO}_{3}$ contents are much higher (90-95\%) and much more uniform, as shown also by the regularity of the $\gamma$-ray curve (Fig. 8), and the clay-mineral content is lower (Fig. 10). The contrast in color between redeposited and hemipelagic sediments is faint. Microfossils, even where relatively concentrated at the bases of cycles, are less abundant and more scattered than in the underlying subunit. The main biogenic components are calcareous nannofossils, with a few Inoceramus prisms and foraminifers (Figs. 9 and 10).

In spite of the dominance of the calcareous components, a terrigenous influx still is recorded, as demonstrated by the complex clay-mineral assemblages, which have similar proportions of chlorite, kaolinite, illite, smectite, and mixed-layer clay minerals (Fig. 10).

\section{Unit 3, Part 3}

This subunit was drilled between 470.35 and $456 \mathrm{~m}$ sub-bottom in Hole 550B and was dated as Danian. The 


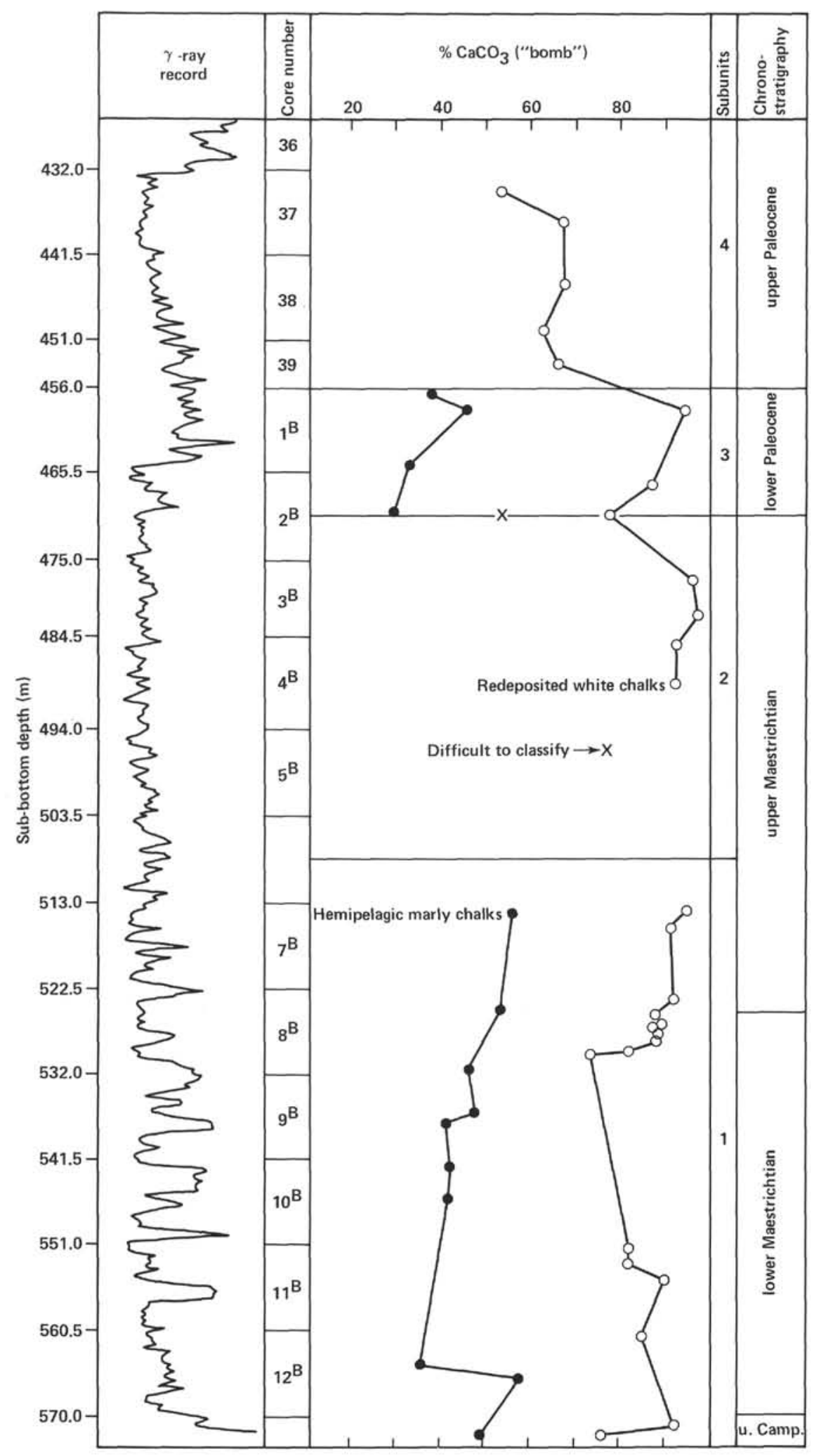

Figure 8. $\gamma$-ray $\log$ and fluctuations of the $\mathrm{CaCO}_{3}$ content in the upper Campanian to Paleocene chalks at Site 550 (Holes 550 and 550B; core numbers with superscript B are from Hole 550B). 


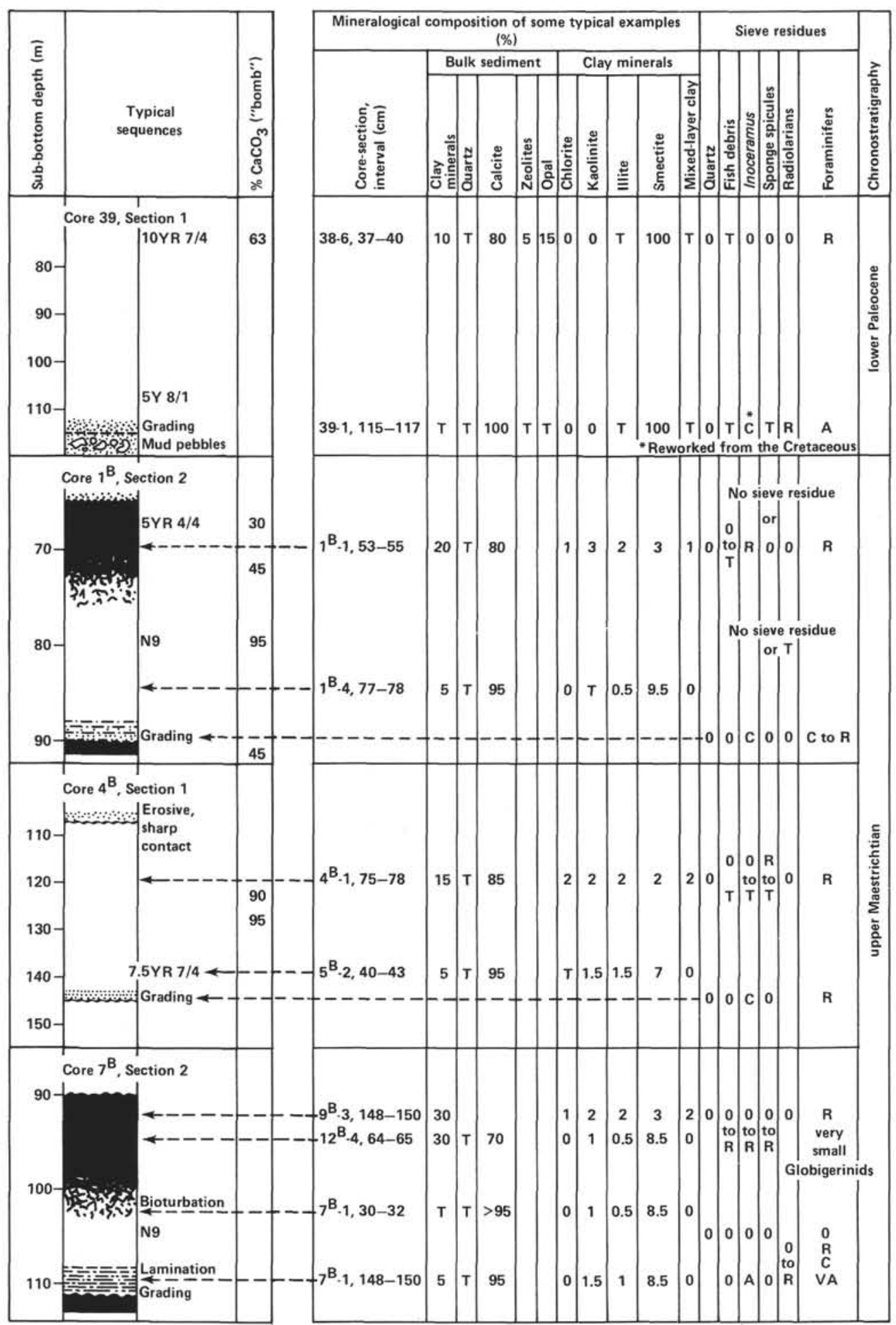

Figure 9. Main components of selected turbiditic sequences in the upper Campanian to Paleocene chalks at Site 550 (Holes 550 and $550 \mathrm{~B}$; core numbers with superscript B are from Hole 550B). Typical sedimentary sequences are shown at left; the mineralogical composition of sediments in those or comparable sequences are shown at right. Abbreviations as defined in Table 1.

lower boundary in Hole $550 \mathrm{~B}$ is at $2-3,36 \mathrm{~cm}$, and in Hole 550 at $39-4,150 \mathrm{~cm}$. The upper boundary in Hole $550 \mathrm{~B}$ is at the top of Core 1. Except for the younger age, Part 3 is comparable to Part 1 : it shows the interbedding of turbiditic cycles, with a highly calcareous $\left(95 \% \mathrm{CaCO}_{3}\right)$ sediment at the base and a more marly one at the top
(30-45\% $\mathrm{CaCO}_{3}$; Fig. 8); color contrasts between pure white at the base and reddish toward the top; grains are very well sorted (Fig. 9; Plate 3, Fig. 1); and terrigenous influence is marked by a diversified clay-mineral assemblage with chlorite, kaolinite, illite, smectite, and mixedlayer clay minerals (Fig. 10). 


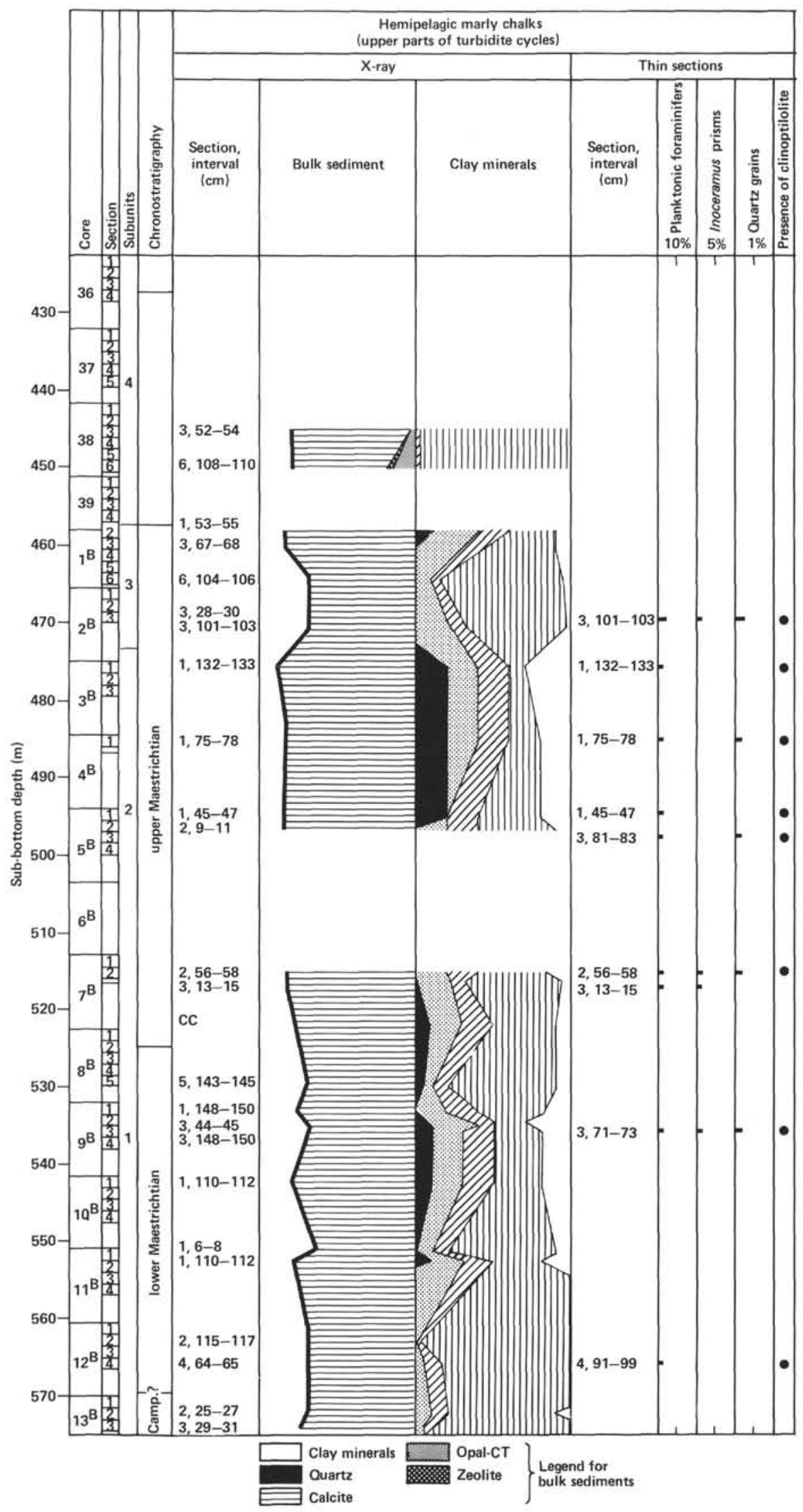

Figure 10. Main components of some typical sediments of the upper Campanian and the Paleocene at Site 550 (Holes 550 and 550B; core numbers with superscript B are from Hole 550B). F indicates sample taken from a mass flow. $\mathrm{M}$ indicates sample from middle of a turbiditic cycle. B indicates sample from base of a turbiditic cycle. 


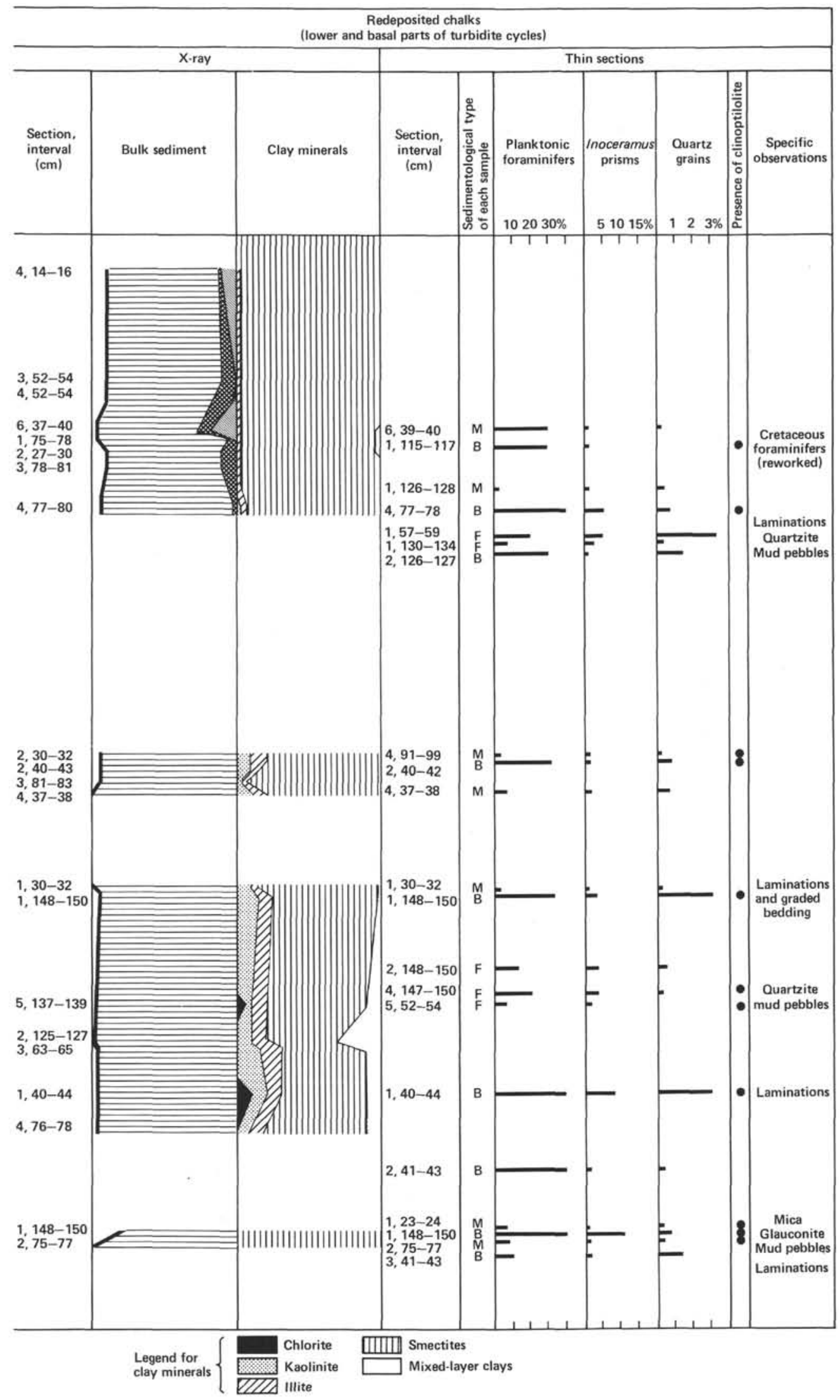

Figure 10. (Continued). 
The main biogenic components are planktonic foraminifers, concentrated just above the erosive surfaces at the bases of the turbidites, and ubiquitous calcareous nannofossils (Fig. 10; Plate 4).

Two mass-flow deposits occupy most of the recovered parts of Cores 2 and 1 from Hole 550B (Plate 2, Figs. 1 and 2). Detrital particles are grains of quartz and quartzites, mud pebbles, Inoceramus fragments, and echinoderm ossicles (Fig. 10).

\section{Unit 3, Part 4}

This subunit is present in Hole 550, 39-4, $150 \mathrm{~cm}(456$ m sub-bottom) through $37-3,95 \mathrm{~cm}(427.50 \mathrm{~m}$ sub-bottom). Its age is late early Paleocene to early late Paleocene. The subunit is comparable to Part 2 , with only minor lithologic differences. The color is rather uniform light gray. The $\mathrm{CaCO}_{3}$ contents range between 75 and $100 \%$ according to X-ray determination, and between 60 and $70 \%$ according to shipboard carbonate-bomb measurements, with a slight increase from bottom to top, as documented by the $\gamma$-ray curve (Fig. 8). Resedimentation is documented by graded sequences resting on sharp contacts in Sections 39-1, 38-6, and 38-4, a slumped bed in Section 39-2, slumped balls in Core 37, and by Inoceramus prisms and calcareous foraminifers reworked from the Cretaceous (Plate 2 and Plate 4, Fig. 1).

Planktonic foraminifers are the only coarse grains present; they are concentrated in the lower parts of turbiditic layers (Figs. 9 and 10). In contrast with the underlying subunits, opal-CT and zeolites are present, and smectite is by far the dominant clay mineral, suggesting high $\mathrm{H}_{4} \mathrm{SiO}_{4}$ activities during the early diagenesis of the sediment (Fig. 10).

\section{Site 550: Conclusion}

Site 550 is approximately $20 \mathrm{~km}$ west of the eastern rifted margin of the early Atlantic, which was approximately $500 \mathrm{~km}$ wide at this location during the Late Cretaceous. This part of the ocean was in the appropriate location for trapping fine terrigenous sediments supplied from distant continental sources during the SantonianConiacian and later in the Maestrichtian. Calcareous biogenic oozes continuously slid and slumped down the slope onto the newly formed ocean floor from the Cenomanian onward. This situation may explain why the sediment accumulation rate here was the highest of the four sites during the Late Cretaceous.

Even though it is the deepest of our four drilled sites, Site 550 shows several unconformities and sediment gaps in the Cretaceous, resulting in part perhaps from its location on a local basement high. Thus, the stratigraphic sequence is more complete-and the accumulation rates even higher-in neighboring depressions of the ocean crust (seismic profile CM 10, site chapter and Masson et al., this volume).

Site 550 was bathymetrically the deepest site on our Goban Spur transect. The Cenomanian limestones of Unit 5 were clearly deposited above the CCD: 95 m.y. ago (late Cenomanian), the water depth was approximately 2000 to $2500 \mathrm{~m}$, according to paleobathymetric reconstructions (Masson et al., this volume). The Santo- nian to Coniacian shales (Unit 4) were probably deposited below the CCD, as suggested by the low carbonate contents of the hemipelagic sediments, by strong dissolution traces on calcareous nannofossils, and by the presence of agglutinated foraminifers without associated calcareous foraminifers. In the Campanian to $\mathrm{Pa}$ leocene chalks (Unit 3), Inoceramus prisms show-on stereoscan electron micrographs (Plate 6, Figs. 7 and 8) - traces of corrosion similar to those observed at Site 548. Corrosion features are also evident on nannofossils and on foraminifers (Müller, this volume; site chapter, this volume) under the optical microscope. However, the high calcareous content of the hemipelagic sediments in this unit indicates that the CCD was deeper than the seafloor at this site during deposition of Unit 3, and that the observed dissolution may be related to diagenetic processes.

Diagenetic processes in the Late Cretaceous at Site 550 can be documented by the development of nearly $100 \%$ pure smectite in the clay minerals of the Coniacian-Santonian shales and the Paleocene chalks. Similar effects could have induced the presence of fluorapatite in the Coniacian-Santonian shales. Also, clinoptilolite is abundant enough in the Paleocene chalks to be detected by X-ray diffraction of bulk samples, and is present in small amounts throughout the Upper Cretaceous section, as shown by thin-section examination.

The evolution of the sedimentary environment at Site 550 during the Late Cretaceous can be summarized as follows: throughout the Late Cretaceous, the Porcupine Abyssal Plain at the foot of the Goban Spur was invaded by turbiditic mud and debris flows. These formed graded sequences (between $10-20 \mathrm{~cm}$ and $1.5-2 \mathrm{~m}$ thick) and massive sequences ( $2 \mathrm{~m}$ or more thick) interbedded with pure foraminifer-nannofossil chalks in the lower part of the sequence and marly nannofossil chalks in the upper part. The redeposited sediments were derived from both the slope-outer shelf area and the continent.

The sedimentation was mainly calcareous, except for a short period of a probable high stand of the CCD during the early Senonian, when water depth was probably 2500 to $3000 \mathrm{~m}$ (Masson et al., this volume). Oxic and anoxic bottom waters were alternating during the Cenomanian, but since then well-oxygenated waters have covered the site, as reflected by the light-colored sediments.

\section{CONCLUSION: EVOLUTION OF SEDIMENTARY ENVIRONMENTS AT THE GOBAN SPUR DURING THE LATE CRETACEOUS}

The situation of Site 548 on a structural high of the Variscan basement did not allow deposition and/or preservation of sediments before the late Campanian. Marine currents may have been responsible for this gap; or more probably, Site 548 was above sea level.

The onset of typical chalky sedimentation in the early middle Cenomanian is recorded at Site 549. Possibly pelagic deposition started earlier in the half-graben to the northeast of the Pendragon Escarpment, as suggested by seismic profiles. At Site 551, on the outer high basement, it began in the late Cenomanian. Cenomanian deposits at both Site 549 and Site 551 show a strong- 
er terrigenous influx than the overlying beds, as documented by the presence of detrital quartz (seen in thin section) and higher contents of illite and mixed-layer clay minerals associated with dominant smectite.

At the deepest site (550), situated on a basement high in the narrow oceanic basin, near the foot of the slope, sediments of the Cenomanian are also carbonate-rich $\left(75-90 \% \mathrm{CaCO}_{3}\right)$, but the clays are nearly pure smectite. Therefore, the site was probably protected from terrigenous influx. Episodic restriction of the water circulation on the sea bottom periodically allowed the preservation of marine organic matter, in strong contrast to the welloxygenated chalks deposited on the slope (Waples, this volume). It therefore appears that in deeper parts of this segment of the narrow early Atlantic ocean, ponded anoxic waters were repeatedly trapped. But free circulation of aerated waters at shallower depths was not interrupted.

An important event in the depositional history of this margin is reflected in a layer of carbonaceous shales and radiolarian cherts near the Cenomanian/Turonian boundary, which was encountered at Sites 549 and 551. The accumulation of organic matter was probably enhanced by a low sedimentation rate at this time. Underlying sediments at both sites contain a significant amount of opal-CT and clinoptilolite, which increases to a maximum in the carbonaceous beds and coincides with an abundance of radiolarian tests. This is considered as indicative of high organic productivity which began as early as the middle Cenomanian but led to deposition of organic-carbon-rich sediment only in the latest Cenomanian. The high-productivity layer may be interpreted as resulting from temporary upwellings (Waples, this volume). An alternative explanation would be the presence of an oxygen-minimum layer located at mid-depth (Waples, this volume) and isolated by circulation below (Site 550) and above (Site 548) for local reasons. Bottom currents at these sites may have prevented deposition of sediments in the middle Cenomanian to early Senonian at Site 550 and in the late Campanian at Site 548 (see the foregoing). The accumulation of sediments rich in organic matter within this short time interval has already been noted for various sites in the North Atlantic (Graciansky et al., 1982) and also in the Tethys (Jenkyns, 1980). It is everywhere dated at approximately the Cenomanian/Turonian boundary, and may be a result of an oceanwide stagnation event (Graciansky et al., 1984).

A sediment gap or a period of highly condensed sedimentation characterizes most of the Turonian over the whole margin and adjacent ocean crust.

In the early Senonian (Coniacian-Santonian), calcareous foraminiferal and nannofossil-bearing chalks were deposited at intermediate depth on the top of the Pendragon Escarpment, and occasionally slid down the slope into deeper waters. In fact, on the neighboring Porcupine Abyssal Plain, calcareous turbidites are interbed- ded with pure dark shales, which probably originated below the CCD. Similar lithologic associations are found as young as the Cretaceous/Tertiary boundary, but after the late Campanian higher calcareous contents in the argillaceous sediments reflect a deepening CCD.

After a variable hiatus in the Campanian, which is recorded at each site, nearly pure chalks (more than $95 \%$ $\mathrm{CaCO}_{3}$ in most cases) were deposited at the three shallower sites $(548,549$, and 551). This shows that sedimentation in the perched half-grabens along the slope was purely biogenic and mostly pelagic (nannofossils and planktonic foraminifers), but much of the pelagic sediment was redeposited by mass-flow processes from the outer shelf or upper slope.

Slight differences occur in the clay-mineral associations of the different sites: at Sites 549 and 551, smectites are widely dominant over minor illite and mixedlayer clay minerals; at Site 548 , even in almost pure calcareous lithologies, the clay-mineral assemblage is more markedly detrital, as smectite is always associated with illite, chlorite, kaolinite, and mixed-layer clay minerals. This may be related to the relative proximity of the shoreline at this shallower site. Pure white chalks were redeposited by gravitational processes from shallower depths onto the Porcupine Abyssal Plain (Site 550). In contrast to the perched basins on the slope, the young oceanic trough received, from the early Senonian onward, terrigenous detritus in the form of significant amounts of varied clay minerals with minor quartz. A bypassing canyon system would therefore have been required for the transport of this terrigenous material.

\section{ACKNOWLEDGMENTS}

The authors are specially indebted to Dr. B. Zinszner and to the technicians of Institut Français du Pétrole, who provided the needed impregnated samples. Stereoscan microscope work was performed at the École des Mines. Standard optical thin sections were prepared at the Institut Français du Pétrole (I.F.P.) and at the Bureau de Recherches Géologiques et Minières (B.R.G.M.) on the recommendation of Dr. A. Lhomer. Financial support was provided by an individual grant, No. 955066, from the Centre National de la Recherche Scientifique. Special mention is due Professors Bernoulli and Hart and Dr. C. W. Poag for critically reviewing this paper. D. Bernoulli is responsible for several additional remarks of critical interest. Useful discussions were held with Drs. Masson and Waples.

\section{REFERENCES}

Graciansky, P. C. de, Brosse, E., Deroo, G., Herbin, J. P., Montadert, L., Müller, C., Schaaf, A., and Sigal, J., 1982. Les formations d'âge Crétacé de l'Atlantique Nord et leur matière organique: paléogéographie et milieux de dépôt. Rev. Inst. Fr. Pet., 37:275-336.

Graciansky, P. C. de, Deroo, G., Herbin, J. P., Montadert, L., Müller, C., Schaaf, A., and Sigal, J., 1984. Ocean-wide stagnation episode in the Late Cretaceous. Nature (London), 308(5957):346-349.

Jenkyns, H. C., 1980. Cretaceous anoxic events: from continents to oceans. J. Geol. Soc. London, 137:171-188.

Zinszner, B., and Meynot, C., 1982. Visualisation des propriétés capillaires des roches réservoir. Rev. Inst. Fr. Pet., 37:337-362.

Date of Initial Receipt: December 14, 1982

Date of Acceptance: August 15, 1983 


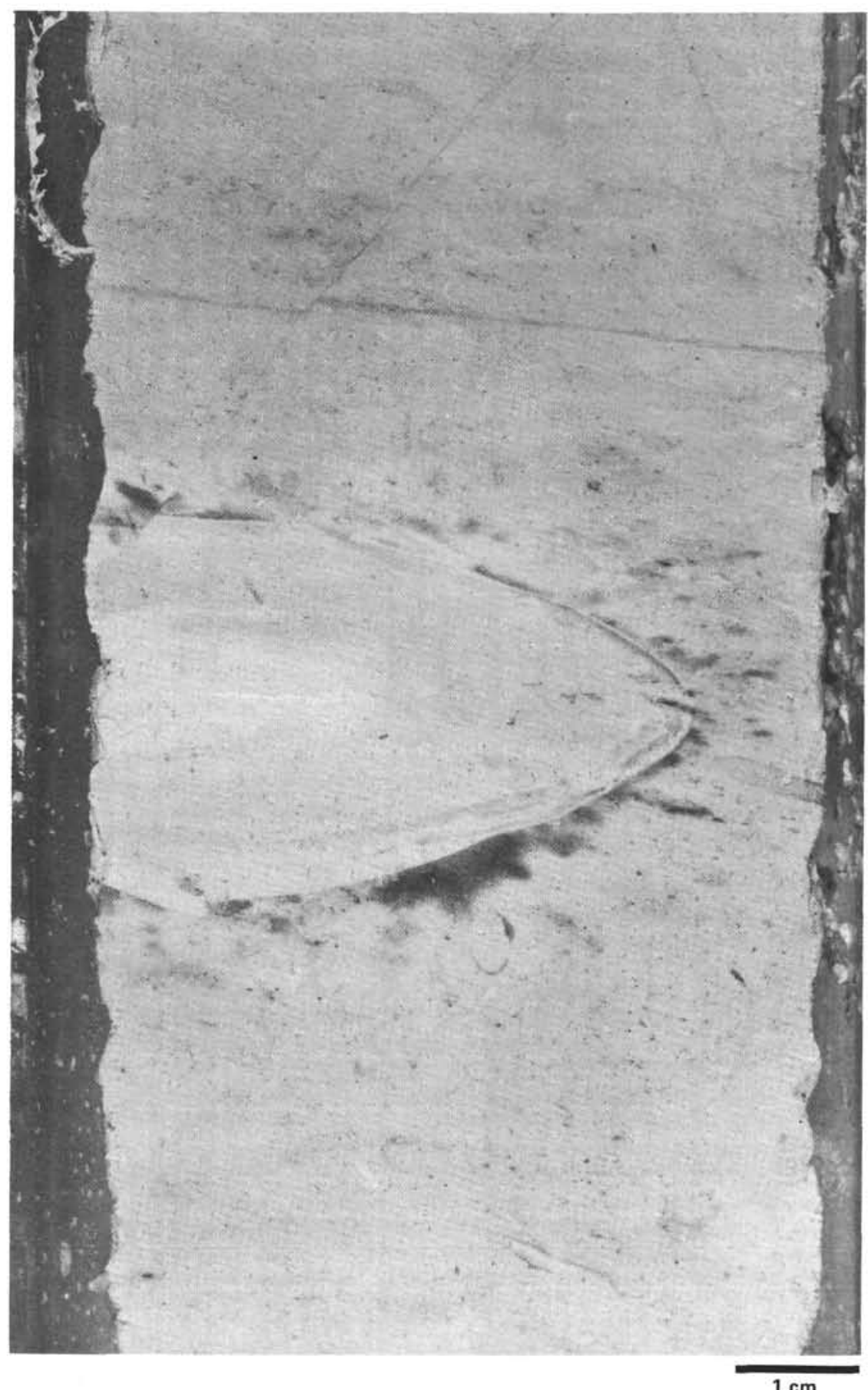

$1 \mathrm{~cm}$

Plate 1. Example of a redeposited mud ball in the Maestrichtian chalks at Hole $548(23-1,75-85 \mathrm{~cm})$. Notice also a small-scale extensional microfault. 

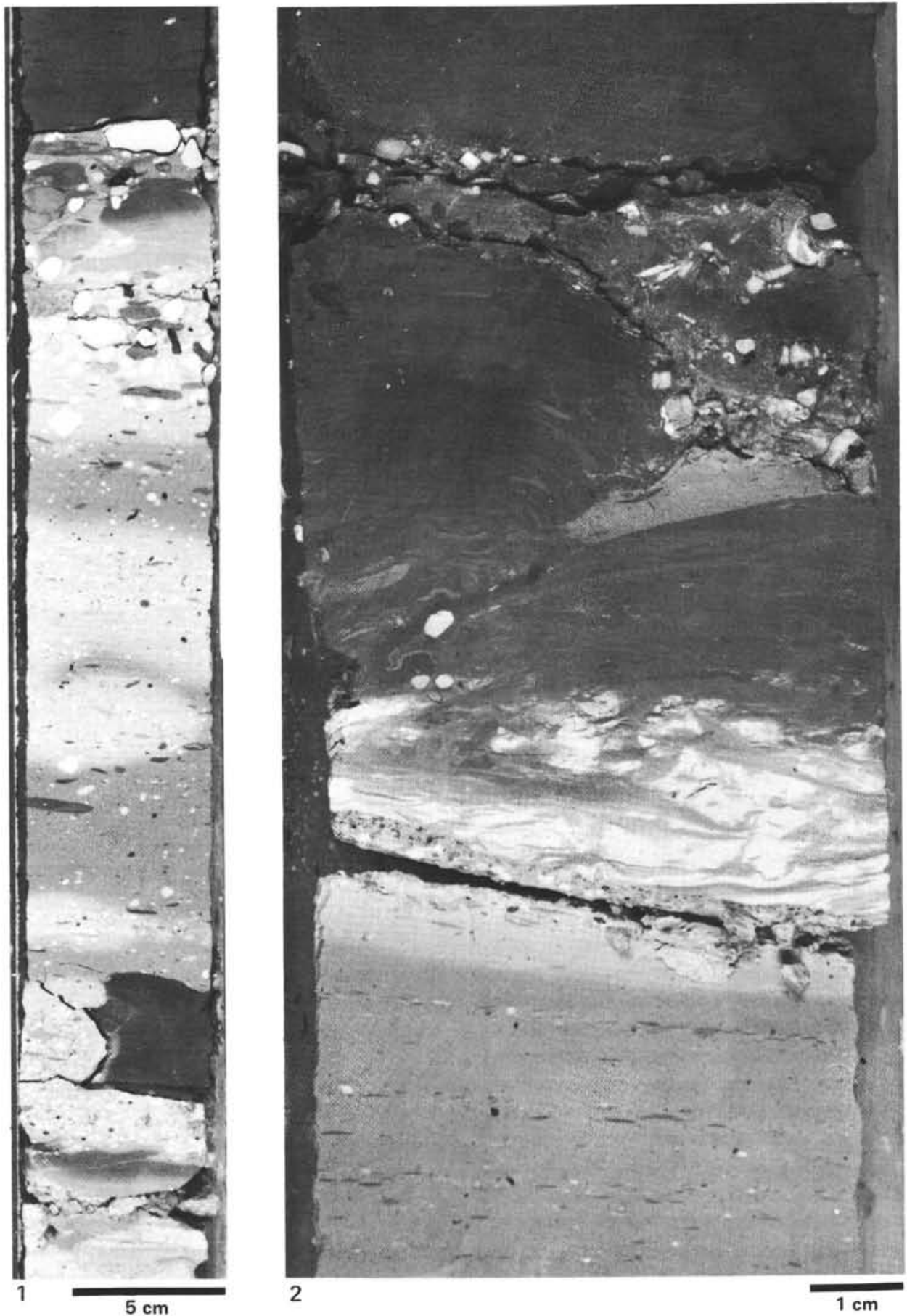

Plate 2. Lower parts of two mass flows, Hole 550B (lower Paleocene). 1. 1-4, 81-122 cm. 2. 1-1, 35-49 cm. The dark sediment below the erosional surfaces (Section 4 at $118 \mathrm{~cm}$ in Figure 1; Section 1 at $47 \mathrm{~cm}$ in Figure 2) is hemipelagic reddish marly nannofossil chalk which belongs to the top of the underlying turbidite. Dark pieces of sediment within the mass flows are composed of the same hemipelagic marly chalk eroded by the mass-flow processes. Smaller white elements are foraminifers and nannofossil-bearing chalks displaced from shallower depths. Thinner and darker components are glauconitic clusters or fragments of mica schists, sericitic schists, or quartzites displaced from the Variscan basement. Lamination at 36,37 , and $38 \mathrm{~cm}$ on Figure 2 is defined by flakes of hemipelagic marly chalk, grains of white chalk, and planktonic foraminifers. 

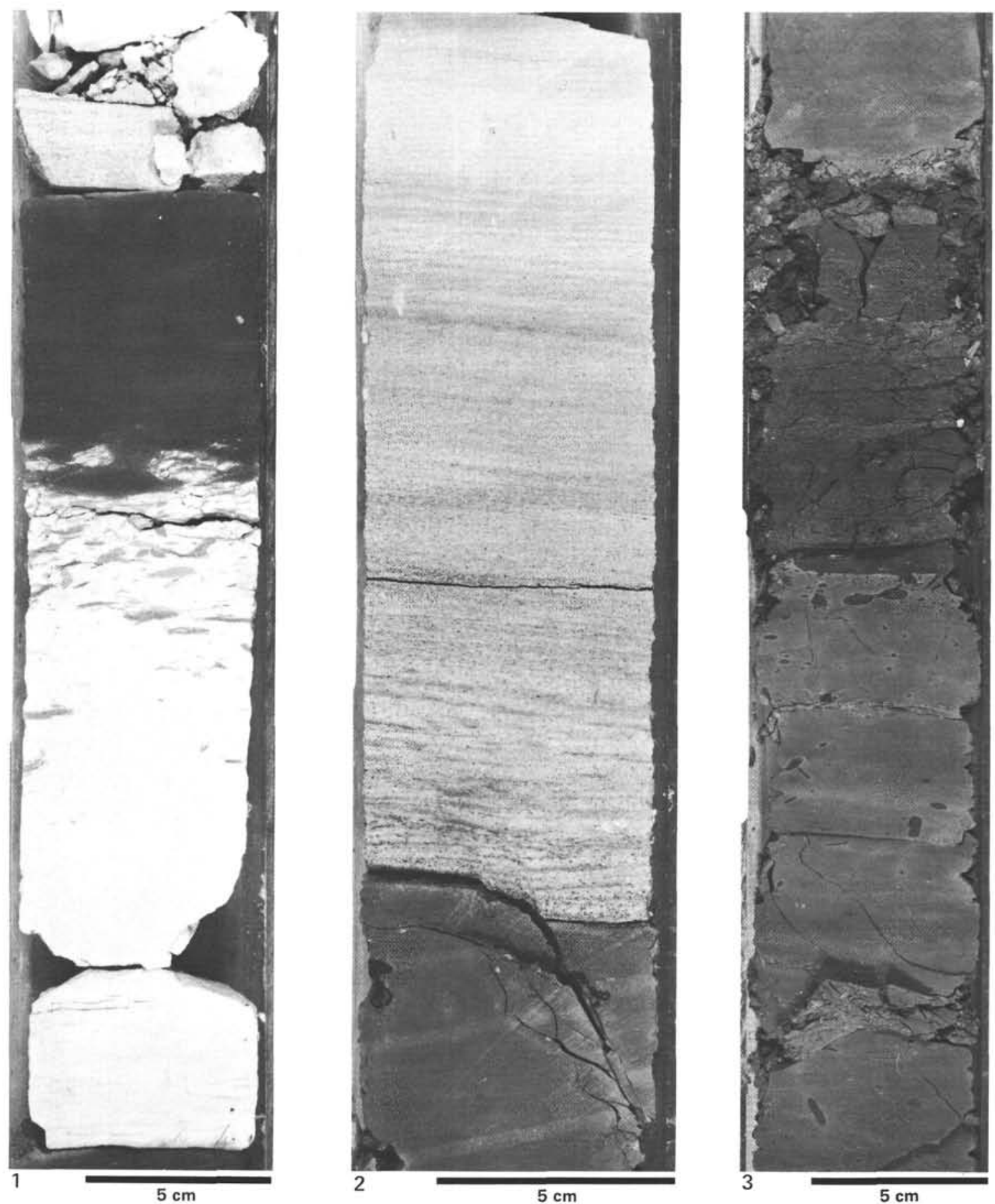

Plate 3. 1. Example of a turbiditic cycle, Hole $550(1-2,79-91 \mathrm{~cm}$; lower Paleocene). The lower boundary is an erosional surface which cuts into the reddish marly nannofossil chalks of hemipelagic origin at $90 \mathrm{~cm}$. The upper boundary is a comparable surface at $64.5 \mathrm{~cm}$. The white sediment is foraminifer-nannofossil chalk of relatively shallow-water origin; lamination near the base $(87-90 \mathrm{~cm})$ results from the accumulation of pelagic foraminifers (including reworked forms from the Maestrichtian); lamination is also conspicuous at the base of the immediately overlying cycle $(62-64 \mathrm{~cm})$. Note the strong burrowing at the transition between the white turbiditic and the red hemipelagic sediments $(71-77 \mathrm{~cm})$. 2. Base of a turbiditic cycle, Hole 550B (11-2, 28-53 cm; lower Maestrichtian). Hemipelagic reddish sediment below $47 \mathrm{~cm}$ is overlain by redeposited chalk, showing parallel and grading lamination. Particles are mostly pelagic foraminifers and Inoceramus prisms. Note a small-scale fault (46-50 $\mathrm{cm}$ ), probably caused by differential compaction of the muddy substratum during the emplacement of the turbidite. 3. Contact between Coniacian carbonate-free claystones and Cenomanian calcareous siltstones, Hole 550B (13-3, 51-84 cm). The contact, visible at $67 \mathrm{~cm}$, is burrowed. It documents a hiatus which comprises Turonian and most probably a part of the underlying and overlying stages. 


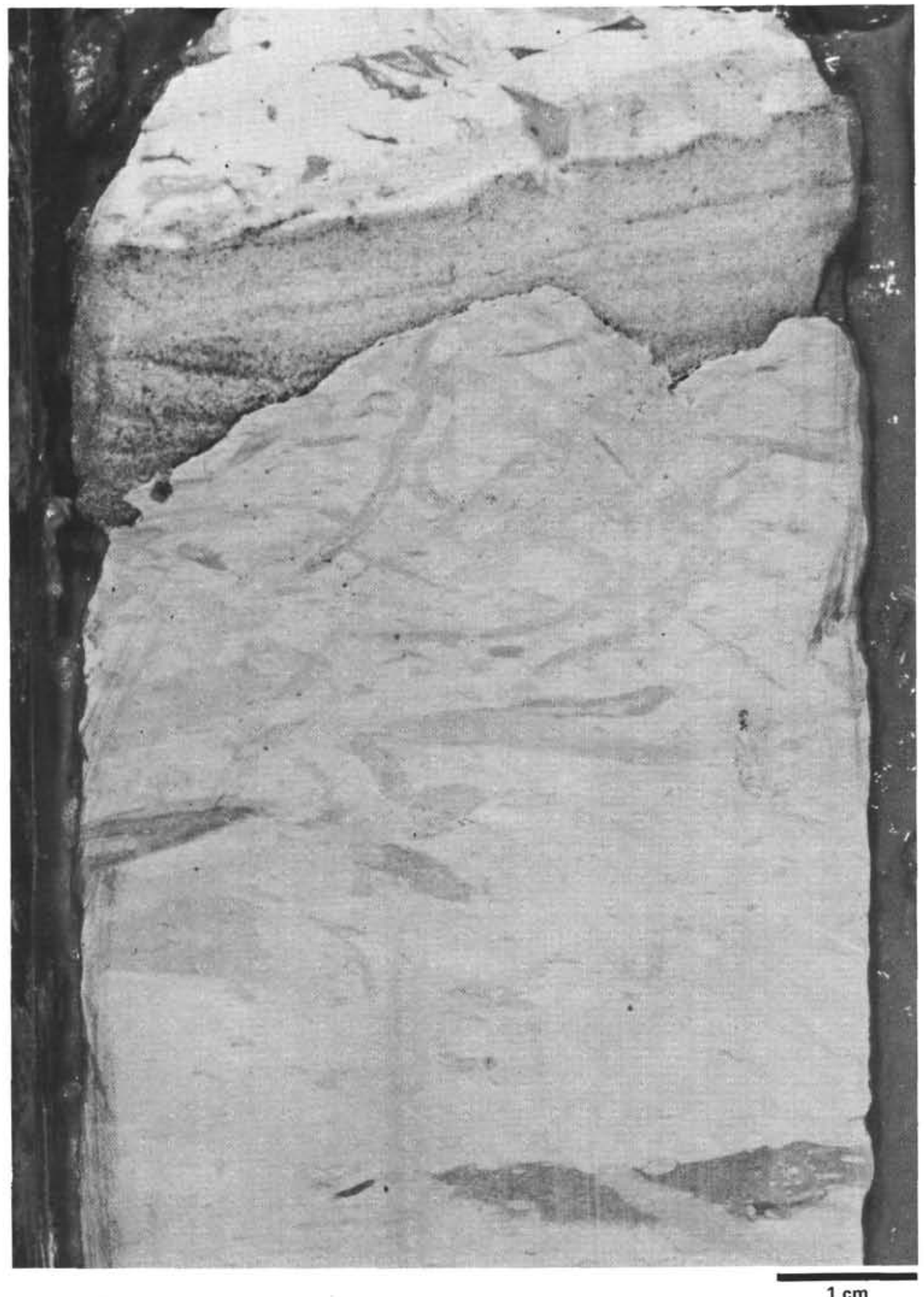

$1 \mathrm{~cm}$

Plate 4. Detail of the contact between two turbiditic cycles, Hole 550B (1-4, 4-14 cm; Danian). In this case, the erosional surface (7-8.5 cm) cuts through white chalk of the middle part of a turbiditic cycle. Burrows below the surface are clearly cut off by the erosional contact. The lowest part of the overlying turbidite is marked by laminated calcarenite composed of planktonic foraminifers and Inoceramus prisms, the latter reworked from the Upper Cretaceous. 

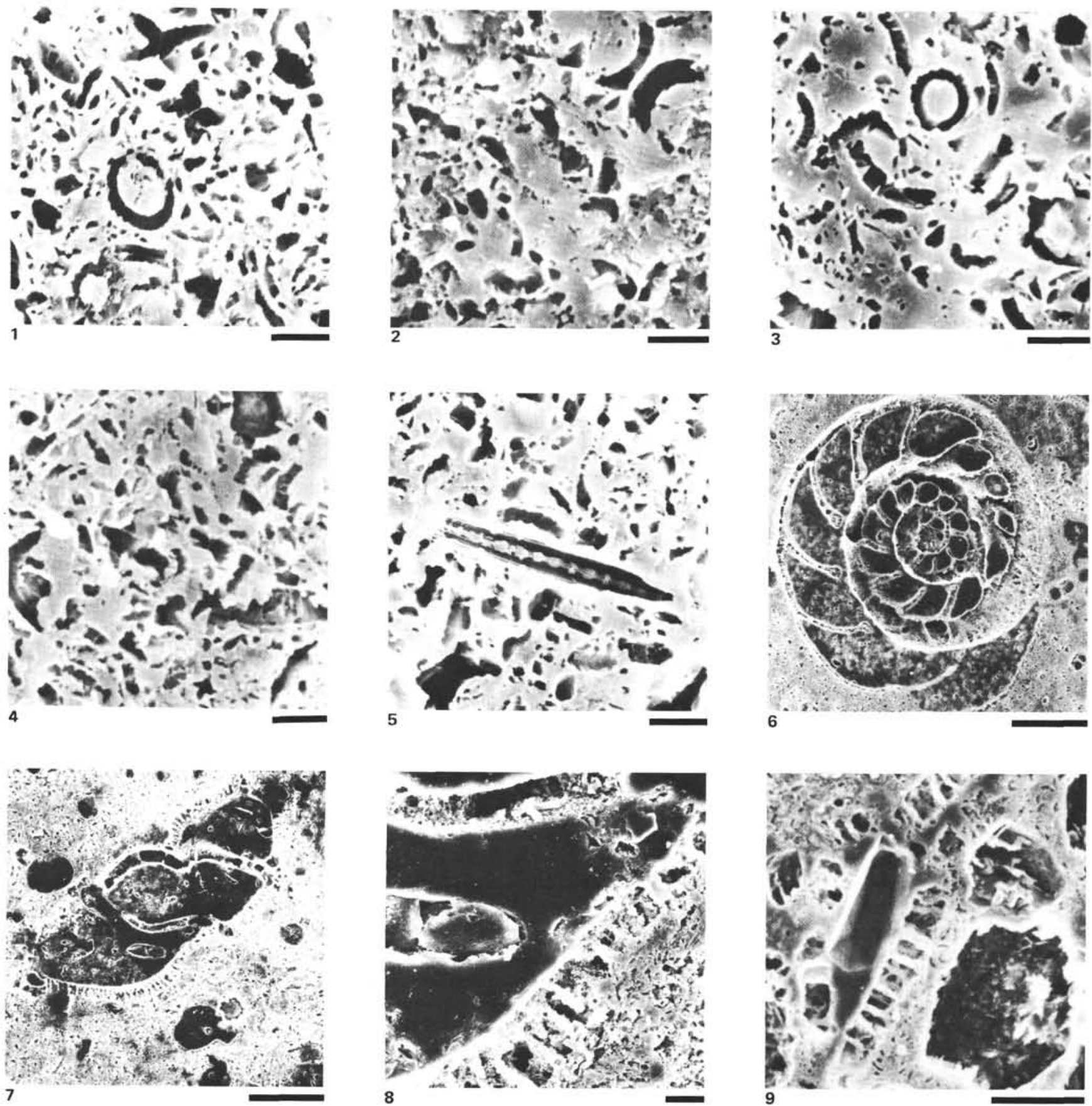

Plate 5. General stereoscan views showing porosity. The illustrations presented here are stereoscan electron micrographs of selected Upper Cretaceous chalks impregnated with colored resin. The impregnation of desiccated samples was performed with a low-viscosity epoxy resin under vacuum, later hardened by a polymerizing catalyst. The calcareous part of the consolidated sample was then dissolved with diluted $\mathrm{HCl}$. Small polished surfaces of the remaining material give a kind of picture of the porosity of the sediment, which is filled with resin, whereas fossil remains appear as molds. In fact, the resin casts may correspond to an interconnected pore-space on a small scale, with tiny crystals of calcite enveloped by the resin. The casts therefore look more massive than they may be in reality. Details on the techniques of preparation are given by Zinszner and Meynot (1982). 1-4. (All scale bars $=5 \mu \mathrm{m}$.) These four pictures, related to the four different holes, show the very similar aspects of the molds left by the artificial dissolution of calcareous nannofossils. The probable volumetric importance of the porosity of these low-compaction chalks is visualized here by the impregnation with resin. 1. Hole 548A (32-4, 37-38 cm; middle Maestrichtian). 2. Hole 549 (26-1, 54-56 cm; Turonian [?]). 3. Hole 551 (4-4, 42-47 cm; upper Campanian). 4. Hole 550B (3-1, 132-133 cm; upper Maestrichtian). 5. Hole 548A (30-1, 103-104 cm; upper Maestrichtian). Scale bar is $5 \mu \mathrm{m}$. A delicate mold of the axial canal of an unidentified spicule. 6-9. Artificial molds of foraminifers. 6. Hole 548A (31-3, 63-65 cm; middle Maestrichtian). Scale bar is $100 \mu \mathrm{m}$. 7. Hole 549 (22-2, 97-98 cm; Maestrichtian). Scale bar is $100 \mu \mathrm{m}$. 8. Detail of Figure 7. Scale bar is $10 \mu \mathrm{m}$. 9. Hole $551(6-2,70-72 \mathrm{~cm}$; upper Cenomanian). Scale bar is $33 \mu \mathrm{m}$. A single Inoceramus prism is associated with foraminiferal shell debris. 

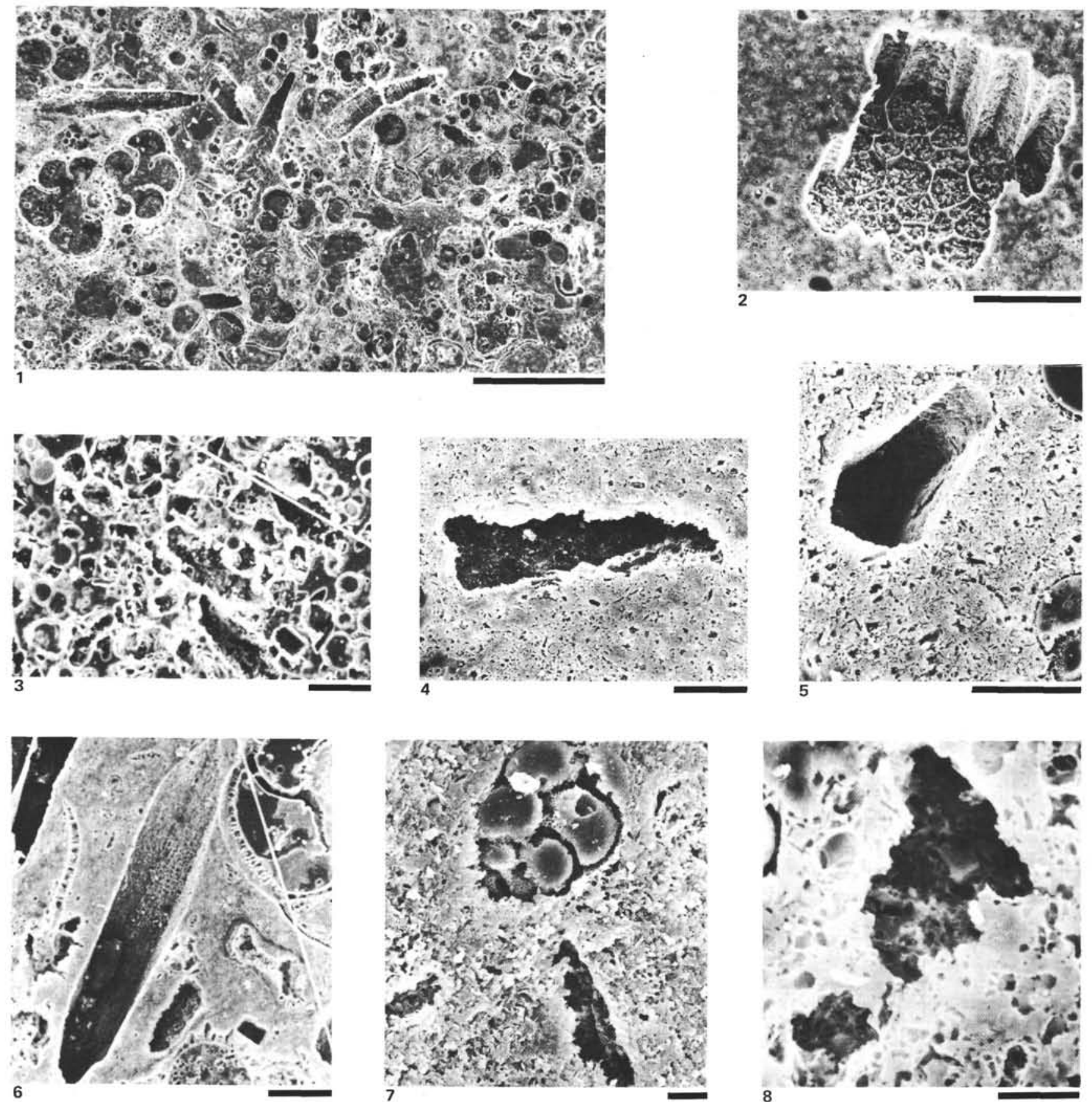

Plate 6. 1. Hole 550B (11-2, 40-43 cm; lower Maestrichtian). Scale bar is $500 \mu \mathrm{m}$. Foraminifers and Inoceramus prisms concentrated at the base of a turbidite. The basal layer of the turbidite is virtually mud-free, with large interparticle pore-space (now resin). 2-8. Molds of Inoceramus prisms, showing various stages of preservation. 2. Hole $548 \mathrm{~A}(31-3,63-65 \mathrm{~cm}$; middle Maestrichtian). Scale bar is $100 \mu \mathrm{m}$. Fragment of an individual Inoceramus shell; prisms are still in connection. Perfect preservation. 3. Hole $551(6-2,76-78 \mathrm{~cm}$; upper Cenomanian). Scale bar is $100 \mu \mathrm{m}$. Well-sorted small foraminiferal tests and Inoceramus prisms. 4. Hole 548A (31-3, 63-65 cm; lower Maestrichtian. Scale bar is $50 \mu \mathrm{m}$. Slightly etched Inoceramus prism. 5. Hole $549(22-2,97-98 \mathrm{~cm}$; Maestrichtian). Scale bar is $50 \mu$ m. Well-preserved Inoceramus prism. 6. Hole 550B (8-5, 52-54 cm; upper Maestrichtian). Scale bar is $100 \mu \mathrm{m}$. Well-preserved Inoceramus prism. 7. Hole 550B (10-4, 76-78 cm; lower Maestrichtian). Scale bar is $10 \mu \mathrm{m}$. Highly corroded Inoceramus prism. 8. Hole 550B (9-2, 125-127 cm; lower Maestrichtian). Scale bar is $10 \mu \mathrm{m}$. Highly corroded Inoceramus prism. 